\title{
U-Eco City 적용기술의 평가항목 도출 \\ Deduction of Assessment Items about Applied Technologies in U-Eco City
}

김지현, 김호기

서울대학교 건설환경공학부

Ji-Hyun Kim(ohora0723@snu.ac.kr), Ho-Kee Kim(ymavus80@snu.ac.kr)

\section{요약}

국내의 여러 지자체와 신도시에서는 U-Eco City를 구축-계획 중에 있으며 정보통신 기술의 발달에 힘입어 다양한 서비스와 기술이 적용되고 있다. 그러나 U-Eco City 사업이 활발히 추진되는데 반하여 기술적용의 객관성 검증을 위한 연구는 매우 드문 실정이다. 본 논문에서는 U-Eco City에 적용되는 기술 의 결정을 위한 기술평가를 목적으로, U-Eco City의 분야별 기술을 검토하고 분야별 기술의 평가항목을 도출하고자 하였다. 이를 위하여 분야별 기술의 진화과정과 기존의 U-Eco City 기술분류체계를 살펴보 고, 개별 기술의 미래적 방향성을 탐지함으로써 장기적 활용이 가능한 U-Eco City 기술평가항목을 제시 하였다. 연구 결과 U-Eco City 기술은 정보 수집기술(센서, 상황인지, 영상인지, 위치인식 기술), 정보 가 공기술(임베디드 $\mathrm{S} / \mathrm{W}$ 기술), 정보 활용 기술(네트워크 기술) 등 총 6 개 분야로 제시되었으며, 이들 기술 의 분야별 평가항목을 도출하였다.

- 중심어 : | U-Eco City 기술 | 평가항목 | 주기율표 |

\section{Abstract}

For assessment of U-Eco City technologies, more concrete definition of those technologies are required. However, almost researches defined technologies as conceptually and even cannot include all of them. In this sense, the purpose of this study is to deduct assessing items for specifying applying priority of U-Eco City technologies. We performed the research by 3 steps. Firstly, we deduct assessing items of the technologies by researching their advance process. After then, we compensate the defect of those items through documentary research and made a periodic table about core technologies that can be useful for deducting long-term items.

The assessing items what are deducted as a result of this study can be applied to the selection of technology, and will be useful to construct more objective and systematized U-Eco City. Furthermore, if assessment frame about technologies and services is developed from this research, it gives to us probability that standardized process of U-Eco City construction can be established.

- keyword : | U-Eco City Technology | Assessing Item | Periodic Table |

\footnotetext{
* 본 논문은 서울대학교 SIR BK21 (안전하고 지속가능한 사회기반건설) 사업단과 국토해양부가 주관하고 한국건설교통기 술평가원이 시행하는 첨단도시개발사업(과제번호 :07-첨단도시 A01)에 의해 수행되었습니다.

접수번호 : \#100127-002

접수일자 : 2010년 01월 27일
} 


\section{1. 서 론}

\section{1 연구의 배경 및 목적}

현재 국내의 여러 지자체와 신도시는 U-Eco City의 구현을 위하여 다양한 서비스와 기술적용을 경쟁적으로 제시하고 있다. 그러나 대부분의 U-Eco City는 아직까 지 설계 및 계획단계에서 벗어나지 못하고 있으며, 구축 모델 역시 정립되지 않은 실정이다. 성공적인 $\mathrm{U}-\mathrm{EcO}$ City 구축모델 수립을 위한 노력은 유비쿼터스의 개념이 대두되기 시작한 2005년 이후부터 꾸준히 진행되었으며, U-Eco City 계획체계의 표준화 구축에 대한 문제제기는 끊임없이 제기되어 왔다[1].

실효성 있는 U-Eco City 구축과 지속적 운영을 위해 서는 이용자들이 체감할 수 있을 만큼 혁신적인 서비스 가 구현되어야 하며, 기존과 차별화된 U-서비스의 운영 을 위해서는 서비스별로 적용되는 기술이 선별되어야 할 것이다. 그러나 현재 추진되고 있는 U-Eco City 어느 곳 에서도 도시차원에 적용되는 기술을 평가하고 선별하는 체계가 구축된 바 없다. 최적의 서비스 구현을 위해서는 질적으로 우수한 기술이 저렴하게 도입되어야 하며, 이 는 U-Eco City에서 구현되는 서비스 뿐 아니라 전체 U-Eco City의 질 향상을 위한 바탕이 될 것이다. 그러나 최적의 U-Eco City 기술 적용을 위한 패러다임은 존재 하지 않으며, 도시의 특성을 고려한 U-기술의 적용방안 에 대한 논의 역시 이루어지지 않은 실정이다. 이에 본 연구에서는 U-Eco City에 적용 가능한 기술을 평가해야 한다는 필요성을 제기하는 바이다.

U-Eco City에 적용되는 기술은 일반적으로 통용되는 기술과는 다른 특성을 가지고 있다. 언제 어디서나 원하 는 서비스를 제공하기 위해 활용되는 U-Eco City 기술 은 첨단 IT 기술과 유사한 의미로 통용될 수 있으나 도 시를 구축하기 위한 기존의 기술에 IT 기술이 융합되는 경우가 많으며, 과거에 존재하지 않던 기술이 새로이 생 성되는 등 역동성과 미래지향성을 그 특징으로 한다. 따 라서 일반적으로 기술을 평가하던 잣대로는 U-Eco City 의 기술을 평가할 수 없다. 일례로, 차도와 보도를 구분 하는 용도로 활용되던 연석이 U-Eco City에서는 스마트 센서를 장착한 스마트 연석으로 개발되어 도시에 적용되
며, 과거에 연석을 평가하던 기준이나 센서를 평가하던 항목으로는 스마트 연석을 평가할 수 없는 난관에 봉착 하게 된다.

이에 본 연구에서는 U-Eco City 적용가능 기술의 평 가를 목적으로 U-Eco City 분야별 기술을 검토하고, 분 야별 기술의 평가항목을 도출하고자 한다. 이를 위하여 첫째, 분야별 기술의 진화과정을 살펴봄으로써 분야별 기술의 핵심적 평가항목을 1 차적으로 도출하고 둘째, 문 헌연구를 바탕으로 U-Eco City 기술이 지녀야할 기능을 검토함으로써 1 차 평가항목을 보완할 것이다. 이후 U-Eco City의 핵심기술에 대한 주기율표를 작성하고, 이들의 흐름을 파악함으로써 장기적 관점에서 요구되는 동태적 평가항목을 도출함으로써 최종 U-Eco City 평가 항목을 제시하고자 한다.

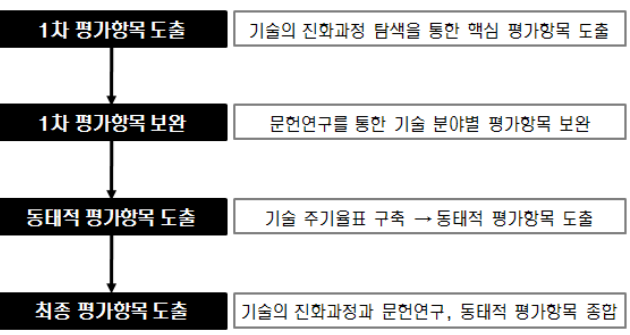

그림 1. 연구의 흐름

\section{2 선행연구 검토}

U-Eco City에 적용 가능한 기술의 평가를 위해서는 'U-Eco City 기술'을 보다 명확히 정의할 필요가 있다. 일반적으로 U-Eco City 기술은 건설 - 정보통신 융합기 술로써 U-Eco City 기반시설 건설 및 유비쿼터스 공간 을 구현하기 위한 기술로 정의되고 있다[2][8][10][11]. 즉, U-Eco City의 정의에 기초한 연구의 수행을 위해서 는 U-Eco City 운영을 위한 가이드라인 구축 및 운영모 델 구축에 대한 고려가 수반되어야 함은 물론 U-Eco City 기술의 기능적 특성에 착안한 기술평가 연구가 선 행되어야 할 것이다. 그러나 현재까지 진행된 연구들을 살펴보면, 거시적 측면에서의 U-Eco City를 고찰한 연 구[1][4][11]와 U-Eco City 구현을 위한 세부 기술에 집 중된 연구[3][5][8][12][14]로 양분되는 것을 알 수 있다. 


\section{표 1. 기존 연구의 U-City 기술 정의}

\begin{tabular}{|l|l|}
\hline \multicolumn{1}{|c|}{ 출처 } & \multicolumn{1}{|c|}{ 기술 정의 } \\
\hline $\begin{array}{l}\text { 국 토 해 양부 } \\
\text { (2008) }\end{array}$ & $\begin{array}{l}\text { U-City 기반시설을 건설하여 U-City 서비스를 제공 } \\
\text { 하기 위한 건설정보통신 융합기술과 정보통신 기술 } \\
\text { (정보수집기술, 정보가공기술, 정보활용기술, 기타기 } \\
\text { 술) }\end{array}$ \\
\hline $\begin{array}{l}\text { 정보통신 } \\
\text { 구 연 진 흥 원 } \\
\text { (2005) }\end{array}$ & $\begin{array}{l}\text { U-City 건설시 제공하고자 하는 서비스를 지원하는 } \\
\text { 기술 (생활형 U-City 기술, 산업형 U-City 기술, 교 } \\
\text { 통/물류형 U-City 기술, 관광/문화ㅎㅕㅕ U-City 기술, } \\
\text { 교육 및 R\&D형 U-City 기술, 글로벌 비즈니스형 } \\
\text { U-City 기술 등) }\end{array}$ \\
\hline $\begin{array}{l}\text { 최 봉 } \\
\text { (2005) 문 }\end{array}$ & $\begin{array}{l}\text { 유비쿼터스 공간을 구현하기 위한 관련 기술 (RFID } \\
\text { 기술, MEMS 기술, 무선통신 관련기술) }\end{array}$ \\
\hline $\begin{array}{l}\text { 이근호·민영 } \\
\text { 훈 (2005) }\end{array}$ & $\begin{array}{l}\mathrm{U} \text {-City의 실질적 구현을 가능케 하는 기술 (RFID, } \\
\text { USN 등 응용기술) }\end{array}$ \\
\hline
\end{tabular}

물론 최근에는 U-Eco City 서비스의 표준체계를 정립 하고, 이를 토대로 서비스 분류기준을 설정하는 연구[9] 가 진행되는 등 U-Eco City 계획체계의 표준화 문제가 일부 논의되고는 있으나, 대부분 U-Eco City 구축을 위 한 정책적 논의에 국한되어 있는 것이 사실이며, 기술과 관련하여 진행되는 연구들 역시 U-Eco City 인프라 기 술 및 $\mathrm{H} / \mathrm{W}$ 기술에 집중[4]되고 있어 도시와 기술의 연 계에 대한 고려가 부족한 실정이다. 전술한 바와 같이, U-Eco City 기술은 일반적인 IT 기술과는 다른 융합 성 - 발전성 등의 특성을 내재하고 있으며, 이에 대한 고 찰 없이는 U-Eco City 기술적용의 타당성 확립이 어려 울 것이다.

이에 본 연구에서는 U-Eco City에 적용 가능한 최적 의 기술을 선별할 수 있는 평가기준 수립을 위하여 개별 기술의 발전 방향을 살펴봄으로써 분야별 기술의 핵심적 기능이 무엇인지를 파악하고, 문헌연구를 토대로 추가적 으로 고려해야 하는 평가 기준을 고찰한 후 개별 기술의 발전과정에서 대두되는 쟁점을 탐색하고자 한다. 단계별 로 도출된 분야별 기술의 핵심 기능 및 쟁점들은 U-Eco City 기술을 평가할 수 있는 지표로 활용 가능하며, 위의 지표를 활용하여 기술평가가 선행될 경우 $\mathrm{U}$-서비스에 최적의 기술을 적용할 수 있는 체계 구축이 가능하다는 장점이 있다. 또한 본 연구에서 제시하고 있는 기술평가 항목을 토대로 U-Eco City 기술을 선별하는 과정이 선 행된다면, 이는 U-Eco City 전반의 질을 높일 수 있는 기제로 작용할 수 있을 것이다.
표 2. U-Eco City 관련 선행연구

\begin{tabular}{|c|c|}
\hline 출처 & 연구 내용 \\
\hline $\begin{array}{l}\text { 강 영 옥 } \\
(2009)\end{array}$ & $\begin{array}{l}\text { U-Eco City 구축을 위한 가이드라인의 표준을 제시하 } \\
\text { 고, 이를 위한 현황 파악 및 핵심 쟁점을 논의 }\end{array}$ \\
\hline $\begin{array}{l}\text { 김복환 등 } \\
(2009)\end{array}$ & $\begin{array}{l}U-C i t y \text { 운영을 위한 선순환 모델의 개발을 위하여 기존 } \\
\text { 의 U-City 현황을 파악하고, 건설비 및 운영비 분석을 } \\
\text { 수ㅎㅐㅐ하여 바람직한 U-City 운영을 위한 선순환 운영모 } \\
\text { 델을 제시하였음 }\end{array}$ \\
\hline $\begin{array}{l}\text { 이근호 등 } \\
\text { (2005) }\end{array}$ & $\begin{array}{l}\text { 기술의 파급성과 적합성을 중심으로 기술관 연관관계를 } \\
\text { 파악하고, U-City에서 활용 가능한 RFID와 USN 기술 } \\
\text { 을 제시하였음 }\end{array}$ \\
\hline $\begin{array}{l}\text { 정경석 등 } \\
(2009)\end{array}$ & $\begin{array}{l}\text { U-City 서비스 표준 확립을 위해 서비스 목록을 구축하 } \\
\text { 고, 서비스 모델 및 운영관리 모델을 구축함으로써 } \\
\text { U-City 서비스 분류기준 및 영역을 정의하였으며 최종 } \\
\text { 적으로 서비스 분류체계를 확립함 }\end{array}$ \\
\hline $\begin{array}{l}\text { 정보통신진 } \\
\text { 흥 연 구 원 } \\
\text { (2005) }\end{array}$ & $\begin{array}{l}\text { U-City 서비스를 생활형, 산업형, 교통/물류형, 곽광문 } \\
\text { 화형, 교육 R\&D형, 글로벌 비즈니스형으로 구분하고 이 } \\
\text { 들 서비스 구현을 위한 네트워크(WPAN) 기술을 고찰하 } \\
\text { 였음 }\end{array}$ \\
\hline $\begin{array}{l}\text { 김 은 형 } \\
\text { (2008) }\end{array}$ & $\begin{array}{l}\text { 지능형 도시공간정보 서비스의 개념을 고찰하고, 서비스 } \\
\text { 모델 표준을 제시함은 물론, 서비스 표준 개발을 위한 표 } \\
\text { 준 항목을 도출하였음 }\end{array}$ \\
\hline
\end{tabular}

\section{2. 평가항목 도출의 범위 및 연구 방법}

\section{1 평가항목 도출의 범위}

U-Eco City의 기술은 서비스를 구현하기 위한 최소 단위이며, 적절한 기술의 도입은 도시의 기능 향상과 최 적 관리를 위한 바탕이라 할 수 있다. 따라서 바람직한 U-Eco City의 구현을 위해서는 체계화된 방법을 통해 기술을 평가해야하며, 이를 근거로 U-Eco City 핵심기 술을 적용하는 과정이 필수적이다. 본 연구에서는 U-Eco City에 적용 가능한 기술의 평가항목을 도출하고 자 하며, 이를 위해서는 기술평가의 범위를 정의해야 한 다[2].

본 연구에서는 U-Eco City는 기술평가의 범위를 국토 해양부에서 제시하고 있는 정보수집기술, 정보가공기술, 정보활용기술로 정의하였으며[2], 이들 기술은 정보수집 기술은 도시정보를 측정할 수 있는 기술로써 센싱기술 (일반센서, 상황인지 - 영상인지 - 위치인식 기술)이 해당 한다[6]. 정보가공기술은 수집된 정보를 서비스 목적에 맞게 최적의 형태로 변경 - 처리하는 기술이며 임베디드 $\mathrm{S} / \mathrm{W}$ 기술이 대표적이다. 정보활용기술은 가공된 정보를 이용자가 활용할 수 있도록 제공하는 기술로써 수집 - 가 
공된 정보를 이용자에게 전송하는 네트워크 기술로 구성 된다. 본 연구에서 기술평가항목 도출의 대상으로 정보 수집, 정보가공, 정보활용 기술을 선정한 이유는 해당 분 류체계가 「유비쿼터스도시의 건설 등에 관한 법률」에 명시된 표준 분류체계로써 다양한 U-Eco City 추진 계 획시 참고되고 있으며, 본 연구의 결과로 도출된 평가항 목의 지속적 활용을 위해서는 표준화된 분류체계에 근거 해야하기 때문이다.

\section{2 연구 방법}

U-Eco City 적용기술의 평가항목 도출을 위한 연구는 세 단계로 진행된다. 첫 번째 단계에서는 U-Eco City 기 술의 분야별 평가항목을 도출하기 위하여 기술의 진화과 정을 살펴보고, 분야별 기술이 어떠한 방향성을 가지고 발전하는지를 토대로 1차적 평가항목을 도출한다. 연구 의 두 번째 단계에서는 문헌연구를 실시하여 기술의 진 화과정에서 검토된 1차 평가항목을 보완 - 검토하고자 하고, 기술의 진화과정에서 추출된 평가항목이 고려하지 못한 기술별 특성을 기술평가에 반영하여 2차 평가항목 을 추출한다. 문헌연구의 대상은 U-Eco City 핵심기술 인 센서, RFID, 유비쿼터스 컴퓨팅, 네트워크 등과 관련 된 책자와 U-Eco City에 대해 서술한 국내외의 연구논 문, 보고서 등이 해당한다. U-Eco City 평가항목 도출의 마지막은 기술의 동태적 평가항목 도출하는 단계이다. 앞서 도출한 U-Eco City 기술의 평가항목은 기술의 진 화과정에서 대두되는 기술적 특성과 일반적으로 고려해 야할 사항을 반영하였다는 점에서 의의가 있으나, 향후 개발될 기술의 방향성을 탐지하고 이를 평가하기에는 미 흡한 점이 있다. 따라서 본 연구의 마지막 단계로써 기술 주기율표를 작성하여, 시간의 흐름에 따른 기술개발의 방향성을 탐지하고 이를 평가할 수 있는 동태적 평가항 목을 구축하였다.

\section{U-Eco City 기술의 평가항목 도출}

\subsection{1 차 평가항목 : 기술의 진화과정 탐색}

기술은 일반적으로 자신의 가치를 극대화시킬 수 있는
방향으로 발전한다. 따라서 기술발전의 주요흐름을 파악 하고 기술적 이슈를 검토하는 과정은 기술이 지녀야 할 성능적 측면을 파악할 수 있는 바탕이 되며, 이러한 탐색 과정을 통해 분야별 기술의 1 차적 평가항목을 도출할 수 있다[7].

\subsection{1 일반 센서}

초기의 센서기술은 센싱 소자와 신호처리회로가 분리 되어있는 형태였다[26]. 온도센서 및 압력센서로 대표되 는 센싱 소자는 단순 인지능 만을 지니고 있었기에 수집 된 정보의 이용을 위해서는 별도의 처리장치를 통해 신 호를 변환해야 했으며, 정보의 변환은 아날로그 신호를 활용하였다. 1960년대 후반 $\mathrm{CMOS}[27]$ 원리가 고안되면 서 아날로그 정보의 디지털방식 보정이 가능해졌고, 저 장되었던 정보를 디지털 방식으로 변환해주는 $\mathrm{ADC}$ 기술 이 추가되며 디지털 센서가 등장하였다. 1970년대 $\mathrm{MEM}[14]$ 기술이 출현한 이후 분리되어있던 신호처리회 로가 센싱소자와 결합되며 집적센서가 개발되었으며, 1990년대에는 마이크로컴퓨터를 센서에 내장할 수 있는 기술이 개발되며 정보의 저장 및 통신, 제어가 가능해졌 고, $\mathrm{SoC}$ 기술의 발달로 모든 기능을 하나의 칩 안에 넣은 지능형 센서가 등장하게 되었다[그림 2].

센서기술은 정보를 수집하는 기능에서 진화하여 다양 한 기능이 집적된 시스템 형태로 변모하고 있으며, 이에 따라 복합화 - 다기능화를 중심으로 기술이 발전하고 있 는 것을 알 수 있었다. 센서기술 진화의 주요쟁점인 집적 화는 센서 자체가 하나의 시스템으로 기능할 수 있도록 마이크로프로세서와 메모리, 센서, 소프트웨어 등이 집 적된 것을 의미하며, 센서의 복합화 - 다기능화는 주변 환경을 감지하는 기능 뿐 아니라 네트워크와 연결되어 정보를 전송하는 것이 가능한 센서기술을 의미한다 [22][31]. 전술된 두 항목은 U-Eco City 기술이 지녀야하 는 필수기능으로 인지되고 있으며, 본 연구에서 도출하 고자 하는 센서의 1 차 평가항목에 해당한다.

\subsection{2 상황인지 기술}

상황인지 기술은 주변 환경의 정보를 수집하는 기술로 써 일반 센서기술과 유사한 특징을 지니고 있으나, 동적 
인 환경 정보의 취득이 가능하다는 점에서 차이를 보인 다[15].

초기의 $\mathrm{RFID}$ 는 군사용으로 개발되었으며 1940년 2차 세계대전을 기점으로 적기와 아군 비행기를 식별하는데 활용되었다. 반면 바코드는 1960년대에 등장한 기술로써 유통-물류분야에서 활용되며 다양한 분야에 적용되었 다. 군용으로 등장한 $\mathrm{RFID}$ 기술이 널리 활용되지 못한데 반하여 바코드는 정보용량 증대를 중심으로 활발한 기술 개발이 진행되었으며, 최근에는 바코드 기술과 $\mathrm{RFID}$ 기 술이 융합되며 차세대 핵심기술로 대두되고 있다[32]. 현 재 $\mathrm{RFID}$ 는 주변 환경이나 개체의 상태를 감지할 수 있 는 지능형 센서의 형태로 진화하고 있으며 태그의 인식 거리 향상과 인식속도 단축, 용량의 증대를 목적으로 발 전되고 있다[15][그림 3].

상황인지 기술의 발전과정을 살펴본 결과, 인식거리와 인식속도, 수명, 데이터용량 및 메모리 용량이 기술진화 의 주요 쟁점으로 도출되었다. 현재 $\mathrm{RFID}$ 의 인식거리는 $27 \mathrm{~m}$ 이하로, 요구되는 서비스 수준에 따라 차이가 있으 나 원거리 인식이 가능할수록 다양한 분야에 응용이 가 능한 것으로 파악되었다. 인식거리를 살펴보면, 바코드

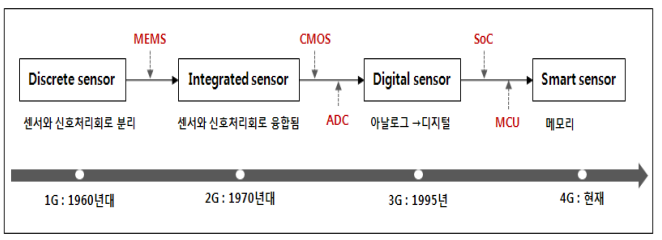

그림 2. 일반 센서 기술의 발전

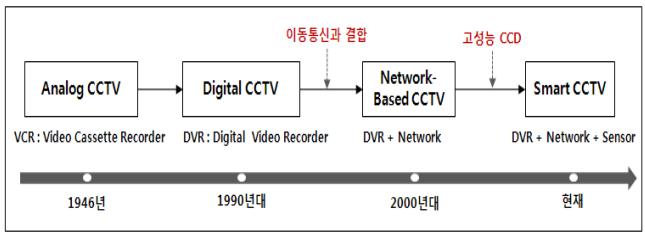

그림 4. 영상인지 기술의 발전

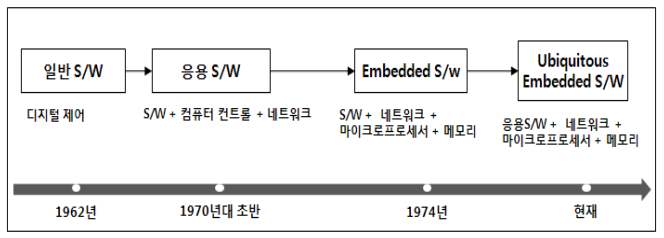

그림 6. 임베디드 $S / W$ 기술의 발전
와 자기카드의 인식거리는 4초, $\mathrm{IC}$ 태그는 1 초, $\mathrm{RFID}$ 는 0.1 초 이하인 것으로 조사되었으며, 인식속도 및 인식거 리가 단축될수록 정보제공의 효율이 증대되어 상황인지 기술의 성능이 향상되는 것으로 나타났다. 이밖에 기기 의 수명연장과 데이터 및 메모리의 용량 증대가 상황인 지 기술이 지녀야하는 필수 기능으로 대두되고 있다.

\section{표 3. 일반 센서의 1 차 평가항목}

\begin{tabular}{|c|l|}
\hline 항목 & \multicolumn{1}{|c|}{ 개념 } \\
\hline 집적화 & $\begin{array}{l}\text { 센서 하나에 다양한 기능 및 요소를 집적시키는 기술을 } \\
\text { 의미하며, 디바이스의 소형화를 위해 센서의 집적화 평가 }\end{array}$ \\
\hline $\begin{array}{c}\text { 복합화다 } \\
\text { 기요항화 }\end{array}$ & $\begin{array}{l}\text { 주볌 환경을 감지하는 초보적 기능 뿐 아니라 네트워크와 } \\
\text { 연결되어 정보를 전송하는 능력 평가가 요구됨 }\end{array}$ \\
\hline
\end{tabular}

\section{표 4. 상황인지 기술의 1 차 평가항목}

\begin{tabular}{|l|l|}
\hline \multicolumn{1}{|c|}{ 항목 } & \multicolumn{1}{|c|}{ 개념 } \\
\hline 인식거리 & $\begin{array}{l}\text { 인식 가능한 거리가 멀수록 적용 가능한 서비스의 범위 } \\
\text { 가 넓어지므로, 인식거리 범위에 대한 평가가 필요함 }\end{array}$ \\
\hline 인식속도 & $\begin{array}{l}\text { 인식속도가 빠를수록 정보처리 효율이 높아지므로, 인식 } \\
\text { 속도 성능에 대한 평가가 필요함 }\end{array}$ \\
\hline 수명 & $\begin{array}{l}\text { 기술의 사용기간을 의미하며, 수명이 연장될수록 기술 } \\
\text { 가치의 경제성이 높으므로, 이에 대한 평가가 요구됨 }\end{array}$ \\
\hline $\begin{array}{l}\text { 데이터·메 } \\
\text { 모리 용량 }\end{array}$ & $\begin{array}{l}\text { 데이터의 저장능력이 뛰어날수록 많은 양의 정보를 담을 } \\
\text { 수 있으므로, 저장용량에 대한 평가항목 필요함 }\end{array}$ \\
\hline
\end{tabular}

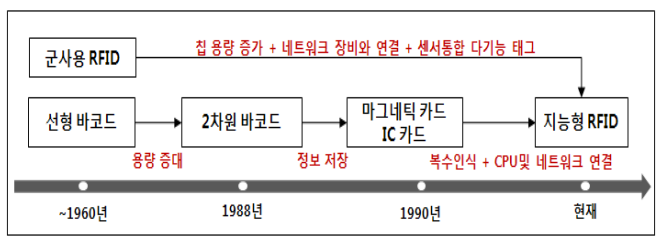

그림 3. 상황인지 기술의 발전

\begin{tabular}{|c|c|c|c|}
\hline \multicolumn{2}{|c|}{ 1G: 군사용 GPS 시대 } & 2G: 민간용 GPS 시대 & \\
\hline NNSS & DNSS & $\longrightarrow$ GPS 민간이용 & $\rightarrow$ GPS 이용확대 \\
\hline $\begin{array}{l}\text { Nayy Navigation } \\
\text { Satellites System }\end{array}$ & $\begin{array}{l}\text { Defense Navigation } \\
\text { Satellites System }\end{array}$ & 1989년 실용위이성 발사 & 1999년 이후 국내 무인원격관측소 욷영 \\
\hline 1960년대 초 & $1973 \sim 1978$ & 1978 1997 & 1997 현재 \\
\hline
\end{tabular}

그림 5. 위치인식 기술의 발전

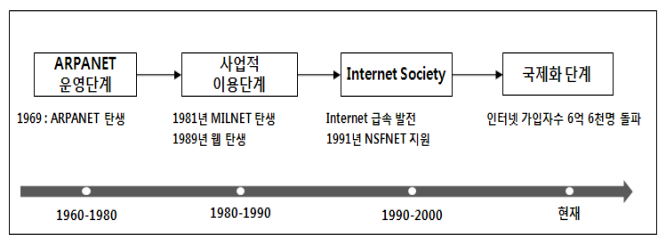

그림 7. 네트워크 기술의 발전 


\subsection{3 영상인지 기술}

영상인지 기술은 주변의 영상정보를 취득하여 서비스 에 적용하는 기술을 의미하며, U-Eco City의 대표적인 영상인지 기술에는 CCTV가 있다.

초기의 CCTV 기술은 보안을 목적으로 1940년대 후반 등장하였다. 이때의 CCTV 기술은 아날로그 방식으로 영상을 저장 - 재생하는 $\mathrm{VCR}$ 방식을 사용하였으며, 영상 신호 증폭기 등의 추가 장비가 필요하다는 단점이 있었 다. 또한 영상신호 증폭성능에 따라 전송거리가 제한적 이었으며 반복 저장으로 인한 화질 저하와 녹화된 영상 물에 대한 열화현상이 발생하는 등의 문제점이 있었다 [29]. 1990년대 이후에는 아날로그 영상신호를 디지털 신 호로 전환하여 저장하는 DVR이 개발되면서 저장된 자 료의 검색 및 재생이 용이해졌으며[28], 2000년대 이후에 는 네트워크 기능 및 이동통신과의 결합되면서 전송거리 확대는 물론 실시간으로 영상을 조회·검색하는 것이 가 능해졌다. 또한 양방향 음성 서비스 및 모션 디렉터, 위 험물 디렉터 등의 다양한 기능이 추가되면서 기존 $\mathrm{CCTV}$ 기술의 한계를 극복하였다[20]. 최근에는 $\mathrm{CMOS}$ 기술이 발전하며 고성능 이미지 센서가 개발되었으며 고 화질 영상정보의 인식이 가능해지고 있다. 또한 일정 영 역을 감시하는 기능뿐만이 아니라 공간 내에서 사용자의 행동을 인지하고, 의도를 파악할 수 있는 기능이 추가되 고 있다[그림 4].

\section{표 5. 영상인지 기술의 1 차 평가항목}

\begin{tabular}{|c|l|}
\hline 항목 & \multicolumn{1}{|c|}{ 개념 } \\
\hline 전송거리 & $\begin{array}{l}\text { 영상인지 기술이 네트워크 기술과 연결되며, 기존에 제한 } \\
\text { 적이었던 영상의 전송이 가능해졌으므로, 이에 대한 평가 } \\
\text { 가 요구됨 }\end{array}$ \\
\hline 화질 & $\begin{array}{l}\text { 아날로그 방식에 비해 디지털 방식의 영상 녹화는 고화질 } \\
\text { 영상정보 인식이 가능해졌으므로, 녹화된 영상의 화질을 } \\
\text { 평가해야 함 }\end{array}$ \\
\hline 실시간성 & $\begin{array}{l}\text { 실시간으로 영상을 조회하고 검색할 수 있는 네트워크 기 } \\
\text { 반의 CCTV 기술이 탄생하였으므로, 영상인지 기술의 실 } \\
\text { 시간성을 평가해야 함 }\end{array}$ \\
\hline 다기능성 & $\begin{array}{l}\text { 영상정보 취득 및 사람의 행동 인지 등 다기능 CCTV로 진 } \\
\text { 화하고 있으므로, 기능의 다양성에 대한 평가가 요구됨 }\end{array}$ \\
\hline
\end{tabular}

영상인지 기술은 시간의 흐름에 따라 녹화 영상의 화 질이 개선되고 기능이 다양화되는 방향으로 발전하고 있 으며, 네트워크 기술과의 접목을 바탕으로 영상정보의
전송거리가 확대되고, 실시간으로 영상정보를 전송할 수 있는 기술적 진화를 이루고 있는 것으로 나타났다.

\subsection{4 위치인식 기술}

위치인식 기술은 GPS 시스템을 이용하여 고정되거나 움직이는 개체의 위치를 인식하는 기술로써 타 기술과 접목되어 U-Eco City에서 구현되는 다양한 분야의 서비 스에 적용된다.

GPS를 이용한 위치인식 시스템은 1950년대 후반 미 해군에서 위치측량 및 군함 항해체계를 마련하기 위해 개발하였던 Transit System에서 출발한 것으로, 군사용 으로 개발 - 활용되었다[13]. 1970년대부터 본격적인 위 성시대가 열리면서 위성을 이용한 위치정보 취득 시스템 이 본격적으로 발전하기 시작하였으나 일반에는 공개되 지 않았다. 1980년대 초반까지 비밀리에 운용되던 위성 측위 시스템은 1984 년 $\mathrm{KAL}-007$ 기 격추사건으로 일반인 에게 완전하게 공개되었다. 정보공개 이후의 GPS 위성 측위 분야는 방범용 GPS, 모바일 GPS, 차량용 GPS 등 다양한 영역에서 활용되며 기술의 발전을 이루고 있으 며, 2010년 이후에는 지진예측에까지 활용될 예정이다 [그림 5].

\section{표 6. 위치인식 기술의 1 차 평가항목}

\begin{tabular}{|l|l|}
\hline \multicolumn{1}{|c|}{ 항목 } & \multicolumn{1}{c|}{ 개념 } \\
\hline $\begin{array}{l}\text { 좌표체계의 정 } \\
\text { 확도 }\end{array}$ & $\begin{array}{l}\text { U-Eco City에서의 정확한 서비스 구현을 위해 좌표 } \\
\text { 체계의 정확성이 구현되어야 하므로, 정확도에 대한 } \\
\text { 평가가 필요함 }\end{array}$ \\
\hline 정보의 보안성 & $\begin{array}{l}\text { U-Eco City 이용자의 위치정보가 노출되지 않도록 } \\
\text { 정보의 보안성이 확보되어야 함 }\end{array}$ \\
\hline
\end{tabular}

위치인식 기술은 군사용으로 개발된 시스템이며, U-Eco City에 적용될 경우 도시의 다양한 영역에 적용 되는 기반 기술이므로 좌표체계의 정확도가 우선적으로 요구된다 할 수 있다[21]. 또한 개인의 위치정보를 기반 으로 다양한 서비스를 구현하고 있으므로, 객체 및 개인 에 대한 정보보안 역시 기술의 주요 쟁점이라 할 수 있다.

\subsection{5 임베디드 S/W}

U-Eco City에서는 다양한 서비스의 구현을 위하여 많 
은 프로그램이 운영되고 있으며, 이의 구현을 위해서는 수많은 소프트웨어가 개발되어 활용되고 있다. 그러나 지나치게 많은 소프트웨어의 구현은 U-Eco City 운영 관리 인력의 부족 및 프로그램 중복 등의 문제점을 야기 할 수 있으며, 이를 해결코자 대두된 것이 임베디드 소프 트웨어이다[30]. 임베디드 소프트웨어는 특정 목적을 구 현하도록 조합된 어플리케이션 기술을 의미하며, U-Eco City에서 구현되는 어플리케이션의 평가항목을 도출하 기 위하여 일반 소프트웨어의 생성에서부터 최근 임베디 드 소프트웨어가 출현하기까지의 과정을 살펴보았다.

1960년대 이전에 등장한 초기의 소프트웨어는 측정된 정보를 컴퓨터에 적용하기 위하여 아날로그 양으로 변환 하는 아날로그 컨트롤러와 함께 쓰였으며 1962년 디지털 컨트롤러가 개발되면서 측정된 정보를 디지털로 저장할 수 있게 되었다. 1970년대 초반, 컴퓨터 컨트롤러가 하드 웨어를 비롯한 일반 소프트웨어를 모두 포함하면서, 네 트워크 기능과 연결되었고 1974년에는 정보 저장 및 프 로그래밍이 가능한 마이크로프로세서가 개발되었다. 이 때의 마이크로프로세서는 임베디드 시스템의 초기형태 로써 프로그램의 저장 및 재호출이 가능한 형태를 갖추 었다[24]. 이후 데이터 처리 능력과 전송 등의 기능에 혁 신적 기능향상이 이루어졌고, 마이크로프로세서와 네트 워크 기능과 더불어 응용 소프트웨어가 탑재되며 임베디 드 소프트웨어가 등장하였다[그림 6].

\section{표 7. 임베디드 $S / W$ 기술의 1 차 평가항목}

\begin{tabular}{|l|l|}
\hline \multicolumn{1}{|c|}{ 항목 } & \multicolumn{1}{c|}{ 개념 } \\
\hline 처리 용량 & $\begin{array}{l}\text { 많은 양의 정보를 처리할 수 있는 임베디드 소프트웨어 } \\
\text { 의 성능 평가가 요구됨 }\end{array}$ \\
\hline 호환성 & $\begin{array}{l}\text { 타 하드웨어 및 소프트웨어와의 상호운용 가능성을 의미 } \\
\text { 하며, 호환성이 높은 소프트웨어일수록 광범위한 활용이 } \\
\text { 가능하므로 이의 평가가 필요함 }\end{array}$ \\
\hline 속도 & $\begin{array}{l}\text { 처리속도가 빠를수록 많은 양의 정보를 처리할 수 있음 } \\
\text { 므로, 임베디드 소프트웨어의 속도에 대한 평가가 필요 } \\
\text { 함 }\end{array}$ \\
\hline 실시간성 & $\begin{array}{l}\text { 데이터 처리를 위한 요구 명령에 실시간 응답이 가능한 } \\
\text { 지 여부를 평가해야 함 }\end{array}$ \\
\hline 라이 센스 & $\begin{array}{l}\text { 다양한 소프트웨어의 개발은 소프트웨어의 저작권 문제 } \\
\text { 를 파생시키며, 이는 비용의 문제로 직결되므로 국내 라 } \\
\text { 이센스 확보율에 대한 평가가 요구됨 }\end{array}$ \\
\hline
\end{tabular}

임베디드 소프트웨어는 기존의 일반 소프트웨어와는 달리 처리 용량이 대형화되고, 다양한 소프트웨어 및 기
기와 호환성이 증대되는 방향으로 발전하고 있으며 빠른 처리속도를 특징으로 한다. 또한 메모리 용량의 증대에 따라 감소하게 된 응답 및 재호출 시간이 임베디드 소프 트웨어 기술의 발전과 더불어 향상되었고, 이에 따라 시 스템의 실시간성이 임베디드 소프트웨어를 평가하는 주 요 항목으로 대두되었다[17]. 다양한 소프트웨어가 혼재 되어 발달함에 따라 개별 소프트웨어의 저작권 문제가 도출되었으며, 이는 프로그램 운영을 위한 비용문제와 직결된다. 따라서 국내 라이센스를 보유한 소프트웨어가 보다 장기적으로 용이하게 활용될 수 있으므로 임베디드 소프트웨어의 주요 평가항목에 포함된다.

\subsection{6 네트워크}

네트워크 시스템은 통신서비스를 제공하는 기반기술 이며, 다양한 기술과 융합하여 정보를 전송하는 역할을 한다. U-Eco City에서 구현되는 대부분의 서비스는 이 동성을 그 특징으로 하며, 이때 무선 네트워크 기술의 지 원여부는 서비스의 성능향상과 직결된다 할 수 있다.

네트워크 기술의 시초는 1970년에 가동되었던 미 국방 성의 연구용 알파넷(ARPANET)과 군사통신용 밀넷 (MILNET)으로, 음성신호만을 전달하는 단순한 형태에 서 시작하였다. 초기의 시스템 체계는 상호 접속 및 연결 이 지원되지 않는 단독 시스템 형태였으며 이후 여러 대 의 컴퓨터와 통신회선을 이용한 복합 시스템으로 발전할 때 까지 유선으로만 활용되었다. 1984년 정보통신 기술 이 사업적 이용단계에 들어서며 네트워크 기술은 사회의 전 영역에 확대되기 시작했고, 1989년 웹 브라우저가 개 발된 이후 Internet Society가 탄생하면서 무선 네트워크 체제가 구축되며 기술의 비약적인 발전이 이루어지기 시 작했다. 2002년 인터넷 가입자 수가 6억 6천명을 돌파하 면서 네트워크 시장은 국제화 단계에 진입하였으며 최근 에는 다양한 센서 기술과 결합되면서 USN(Ubiquitous Sensor Network)이라는 진보된 기술체계 양산하며 디 지털 네트워크 시대를 이끌어 내고 있다[31][그림 7].

현재의 네트워크 기술은 통신거리에 의해 구분되는 것 이 일반적이며 WPAN, WLAN, WMAN, WWAN으로 구분된다. WPAN(Wireless Personal Area Network)은 $20 \mathrm{~m}$ 이하의 통신거리를 갖는 네트워크로, 데이터 전송 
률이 높고 전력소비가 적다는 특성이 있다. 대표적 $\mathrm{WPAN}$ 기술로는 Bluetooth, 적외선통신(IrDA), ZigBee, $\mathrm{UWB}$ 등이 있으며, 통신거리가 짧다는 한계를 극복하기 위해 이동성 및 처리용량 향상을 목적으로 기술이 발전 되고 있다. WLAN(Wireless Local Area Network)은 통 신거리 $100 \mathrm{~m}$ 이내의 지역에서 고성능의 무선통신을 제 공하는 기술로써 $\mathrm{Wi}-\mathrm{Fi}$ 등으로 대표된다. 지자체를 중 심으로 구현되는 U-Eco City의 특성상 다양한 서비스 구현을 위한 기반기술로 WLAN 기술이 대두되고 있다. WMAN(Wireless Metropolitan Area Network) 기술은 Local영역과 Wide 영역의 중간범위를 서비스하는 통신 망으로, 광범위한 지역의 통신을 위해 활용되는 기술이 다. 대표적 WMAN 기술에는 Wibro가 있으며 고속통신 에 대한 이용자의 요구 충족을 중심으로 기술 발전을 이 루고 있다. WWAN(Wireless Wide Area Network)기술 은 광역통신망으로 불리며, 일반적으로 여러 행정구역 및 국가 사이의 통신을 위해 사용된다. WWAN은 $\mathrm{HSDPA}$ 로 대표되며 다른 네트워크 기술과는 달리 이동 통신(Mobile) 네트워크를 중심으로 기술적 발전이 이뤄 지고 있다.

네트워크 기술의 발전방향을 살펴본 결과 공통적으로 활용되는 용도에 따라 전송거리, 이동성, 처리용량, 통신 속도 등이 중요시되는 것으로 나타났다.

\section{표 8. 네트워크 기술의 1 차 평가항목}

\begin{tabular}{|c|l|}
\hline \multicolumn{1}{|c|}{ 항목 } & \multicolumn{1}{|c|}{ 개념 } \\
\hline 전송거리 & $\begin{array}{l}\text { AP와 단말기 사이의 데이터 전송 가능거리를 의미하며 } \\
\text { 전송거리길수록 광대역 통신 서비스 제공이 가능하므 } \\
\text { 로, 이에 대한 평가가 요구됨 }\end{array}$ \\
\hline 이동성 & $\begin{array}{l}\text { 단말기의 휴대성과 동일한 의미로 사용되며 단말기의 크 } \\
\text { 기와 무게, Seamless 등을 평가함 }\end{array}$ \\
\hline 처리용량 & $\begin{array}{l}\text { 통신1회당 처리할 수 있는 용량을 평가하며, 처리용량이 } \\
\text { 클수록 많은 정보를 송수신할 수 있음 }\end{array}$ \\
\hline 통신 속도 & $\begin{array}{l}\text { 네트워크 또는 시스템간 데이터 전송속도를 의미하며, 이 } \\
\text { 속도가 빠를수록 많은 양의 데이터를 전송할 수 있으므로 } \\
\text { 이에 대한 평가가 필요함 }\end{array}$ \\
\hline
\end{tabular}

\subsection{2차 평가항목 : 문헌연구}

앞서 도출된 1차 평가항목 도출의 목적은 U-Eco City 핵심 기술의 진화과정과 쟁점을 파악하고, 이를 통해 주 요 요구사항을 판단하여 기술의 우수성을 평가하는 항목
을 추출하는 것이다. 그러나 기술이 본연적으로 갖추어 야 할 기능에 대한 평가가 선행되지 않는다면, U-Eco City 기술이 갖추어야 할 기본적 성능을 평가할 수 없다 는 문제가 발생할 수 있다. 따라서 본 연구에서는 문헌연 구를 실시하여 기술별 특성에 따라 기본적으로 요구되는 항목을 검토하였으며, 이를 바탕으로 기술의 진화과정에 따른 평가항목 도출에서 고려하지 못한 항목을 평가에 반영하고자 한다.

\subsection{1 일반 센서}

일반 센서기술은 크게 센서 자체의 기술성을 요하는 부분과 유비쿼터스 센서로써의 기능을 요하는 부분으로 나누어 평가할 수 있다. 센서 자체의 기술성 평가는 센싱 소자가 본래의 처리 기능을 얼마나 잘 수행하는가를 나 타내주는 항목으로, 센싱소자 기술성 평가의 항목으로는 분해능, 감도, 선형성, 범위 등이 있다. 유비쿼터스 센서 의 평가는 USN[5]을 구현하기 위해 갖춰야 할 센서의 기본적 요건을 의미하며, 대표적 항목으로는 센서의 크 기, 무게, 전력, 기능의 다양화 등이 해당한다.

\section{표 9. 센서기술의 2 차 평가항목}

\begin{tabular}{|c|c|}
\hline 항목 & 개념 \\
\hline 분해능 & $\begin{array}{l}\text { 센서 측정범위 내의 최소크기 단위 } \\
\text { 분 해 능 }=\frac{\text { 전 체 영 역 }}{2^{n}}\end{array}$ \\
\hline 감도 & $\begin{array}{l}\text { 입력변화에 대한 응답의 출력변화 비율로, 고감도센서일 } \\
\text { 수록 출력 값의 변화비율 큼 }\end{array}$ \\
\hline 선형성 & $\begin{array}{l}\text { 입력변화와 출력변화 사이의 관계를 나타내며, 선형성을 } \\
\text { 가진 센서일수록 입:출력 변화가 같음 }\end{array}$ \\
\hline 범위 & $\begin{array}{l}\text { 센서가 생성할 수 있는 최소출력과 최대출력 사이의 차 } \\
\text { 이를 의미함 }\end{array}$ \\
\hline 응답 시간 & $\begin{array}{l}\text { 센서 출력이 전체 변화에 어느 정도까지 다다르는데 요 } \\
\text { 구되는 시간으로, 전체 변화의 } 95 \% \text { 를 기준으로 함 }\end{array}$ \\
\hline 신뢰성 & $\begin{array}{l}\text { 온전하게 시스템이 운용된 시간을 운용 횟수로 나눈 비 } \\
\text { 율로써 신뢰성이 높을수록 값이 큼 }\end{array}$ \\
\hline 정확성 & $\begin{array}{l}\text { 센서의 출력이 기대치에 얼마나 근접되어 있는지 정의하 } \\
\text { 며, 정확성이 높을수록 센서의 성능은 높아짐 }\end{array}$ \\
\hline $\begin{array}{l}\text { 반복정밀 } \\
\text { 도 }\end{array}$ & $\begin{array}{l}\text { 같은 입력에 대한 응답이 수차례 측정되었을 경우 출력 } \\
\text { 값이 변화한 정도를 측정하며, 반복정밀도가 높을수록 } \\
\text { 센서의 성능은 높아짐 }\end{array}$ \\
\hline 크기 & $\begin{array}{l}\text { 손목시계나 의복, 신발 등에 부착할 수 있도록 초소형의 } \\
\text { 센서가 필요하므로 MEMS 기술의 구현여부를 평가해야 } \\
\text { 함 }\end{array}$ \\
\hline 무게 & $\begin{array}{l}\text { 초경량 센서일수록 기계장치의 유동성을 증가시키므로, } \\
\text { 무게에 대한 평가 필요함 }\end{array}$ \\
\hline 전력 & $\begin{array}{l}\text { 센서노드가 설치되는 장소는 물리적인 접근이 불편하거 } \\
\text { 나 쉽지 않은 곳이 많으므로, 최대한 전력소모가 적도록 } \\
\text { 설계되어야 함 }\end{array}$ \\
\hline 다기능성 & USN을 구현하기 위한 센서 기능의 다양화 정도 \\
\hline
\end{tabular}




\subsection{2 상황인지 기술}

상화인지 기술은 $\mathrm{RFID}$ 의 기술적 특징을 평가하는 부 분과 유비쿼터스 $\mathrm{RFID}$ 로써의 기능을 평가하는 부분으 로 구분할 수 있다. $\mathrm{RFID}$ 의 기술적 특징 평가는 태그와 리더기로 구성된 $\mathrm{RFID}$ 의 시스템적 특징[25]에서 대두되 는 이슈들을 평가하는 것으로, RFID 태그의 읽기 - 쓰기 능력, 전력공급방식, 태그의 인식률, 사용 주파수 대역 등과[16] RFID 리더기의 인식거리, 메모리용량, 전력소 모량, 충돌방지성 등[18]을 평가한다. 유비쿼터스 RFID 평가항목은 $\mathrm{USN}$ 을 구현하기 위하여 RFID가 갖춰야하 는 기본적 요건을 평가하는 것으로 태그의 가격, 태그의 크기, 멀티 주파수의 대응성 등[15]이 해당한다.

\section{표 10. 상황인지기술의 2 차 평가항목}

\begin{tabular}{|c|c|c|}
\hline \multicolumn{2}{|r|}{ 항목 } & 개 \\
\hline \multirow{4}{*}{$\begin{array}{l}\mathrm{R} \\
\mathrm{F} \\
\mathrm{I} \\
\mathrm{D} \\
\text { 택 }\end{array}$} & $\begin{array}{l}\text { 읽기·쓰기 } \\
\text { 능력 }\end{array}$ & $\begin{array}{l}\text { 기본적으로 읽가쓰기가 가능한 태그일수록 좋으 } \\
\text { 나, 고가이므로 목적에 따라 읽가쓰기능력의 보 } \\
\text { 유여부를 평가함 }\end{array}$ \\
\hline & $\begin{array}{l}\text { 전력공급방 } \\
\text { 식 }\end{array}$ & $\begin{array}{l}\text { RFID는 태그 내 배터리 저장 여부에 따라 능동 } \\
\text { 형 태그와 수동형 태그로 구분되며 용도 및 특징 } \\
\text { 에 따라 적합한 태그를 선택했는지 평가함 }\end{array}$ \\
\hline & 주파수 & $\begin{array}{l}\text { RFID 시스템은 각 주파수의 영역대에 따라 다른 } \\
\text { 특성을 가지고 있으므로, 목적에 부합하는 주파 } \\
\text { 수 영역대가 선정되었는지를 평가해야 함 }\end{array}$ \\
\hline & 인식률 & $\begin{array}{l}\mathrm{RFID} \text { 는 인식 대상물이 금속인 경우 인식 정밀도 } \\
\text { 가 저하되며 인식 거리에 따라 오류가 발생하므 } \\
\text { 로, 인식오류문제의 극복정도를 평가함 }\end{array}$ \\
\hline \multirow{4}{*}{$\begin{array}{l}R \\
F \\
\text { I } \\
D \\
D \\
\text { 리 } \\
\text { 기 }\end{array}$} & 인식거리 & $\begin{array}{l}\mathrm{RFID} \text { 는 서비스 특성에 따라 리더기와의 인식거 } \\
\text { 리가 달라지며 지나치게 길 경우 여러 개의 정보 } \\
\text { 가 인식되므로 적정 인식거리를 평가함 }\end{array}$ \\
\hline & $\begin{array}{l}\text { 메모리 용 } \\
\text { 량 }\end{array}$ & $\begin{array}{l}\text { 메모리 용량이 클수록 많은 데이터를 저장할 수 } \\
\text { 있으므로 이에 대한 평가를 수행함 }\end{array}$ \\
\hline & 전력소모량 & $\begin{array}{l}\text { 전력효율이 높을수록 RFID 태그의 동작에 필요 } \\
\text { 한 고주파 전력을 송출하고 태그에 필요한 데이 } \\
\text { 터를 보내는데 용이하므로 이를 평가함 }\end{array}$ \\
\hline & $\begin{array}{l}\text { 충돌 방지 } \\
\text { 성 }\end{array}$ & $\begin{array}{l}\text { RFID 는 하나의 리더기에서 여러 개의 태그를 } \\
\text { 동시에 인식할 수 있어야 하므로 오류 없이 일괄 } \\
\text { 인식할 수 있는 태그의 개수를 평가함 }\end{array}$ \\
\hline \multirow{3}{*}{$\begin{array}{l}\text { 유 } \\
\text { 번 } \\
\text { 췃 } \\
\text { 스 } \\
\mathrm{R} \\
\mathrm{F} \\
\mathrm{I} \\
\mathrm{D}\end{array}$} & 태그 가격 & $\begin{array}{l}\text { RFID의 경제성은 태그의 가격에 의해 평가되므 } \\
\text { 로, 태그의 가격을 조사평가함 }\end{array}$ \\
\hline & 크기 & $\begin{array}{l}\text { 다양한 상품에 RFID를 적용하기 위해서는 RFID } \\
\text { 의 소형화가 필요하나, 통신거리의 제약을 극복 } \\
\text { 하기 위해서는 어느 정도의 두께가 필요하므로 } \\
\text { 적합한 크기의 RFID를 평가함 }\end{array}$ \\
\hline & $\begin{array}{l}\text { 멀티 주파 } \\
\text { 수 대응성 }\end{array}$ & $\begin{array}{l}\text { 기존 주파수의 사용에 교란을 일으키지 않는 } \\
\text { RFID의 멀티주파수 대응성을 평가함 }\end{array}$ \\
\hline
\end{tabular}

\subsection{3 영상인지 기술}

일반적으로 영상인지 시스템은 피사체의 영상을 얼마
나 정확하게 표현하는가를 평가하는 것으로써 $\mathrm{CCTV}$ 의 영상 입력 부분과 출력부분을 구분하여 수행한다. 영상 입력부분의 평가는 U-Eco City의 다양한 영상정보를 수 집할 수 있는 능력을 평가하는 것으로써 초점거리와 $\mathrm{F}$ Number, 화각 등의 성능을 평가한다. 영상 출력부분의 평가는 수집된 정보를 얼마나 정밀하게 표현할 수 있는 가를 평가하는 것으로써 화소 수, 유효 화소 수, Signal Noise, 해상도 등이 이에 해당한다[23].

\section{표 11. 영상인지기술의 2차 평가항목}

\begin{tabular}{|c|c|c|}
\hline \multicolumn{2}{|r|}{ 항목 } & 개념 \\
\hline \multirow{3}{*}{ 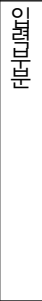 } & F Number & $\begin{array}{l}\text { 렌즈에 입사되는 광량을 측정하는 수치로써, F값 } \\
\text { 이 클수록 발기는 줄어듦 }\end{array}$ \\
\hline & 초점거리 & $\begin{array}{l}\text { 렌즈를 통해 볼 수 있는 피사체의 크기를 결정하 } \\
\text { 는 요소로써 초점거리가 길수록 피사체를 크게 } \\
\text { 볼 수 있음 }\end{array}$ \\
\hline & 화각 & $\begin{array}{l}\text { 영상을 볼 수 있는 회전 범위를 의미하며 넓은 } \\
\text { 화각을 가질수록 광학 촬영이 가능하고 좁은 화 } \\
\text { 각을 가질수록 망원이 가능하므로 용도에 맞는 } \\
\text { CCTV를 평가함 }\end{array}$ \\
\hline \multirow[t]{4}{*}{ 출 } & 화소 수 & $\begin{array}{l}\text { 화소 수는 영화상을 형성하는 최소의 단위로써 } \\
\text { 화소 수가 많을수록 해상도가 높은 영상을 얻을 } \\
\text { 수 있으므로 이에 대하여 평가함 }\end{array}$ \\
\hline & 유효 화소 수 & $\begin{array}{l}\text { 유효 화소 수는 실제 영상신호로 출력되는 유효 } \\
\text { 화소 수가 높을수록 해상도가 높은 고화질의 영 } \\
\text { 상을 출력할 수 있으므로 CCTV를 평가하는 주 } \\
\text { 요기준으로 활용함 }\end{array}$ \\
\hline & $S / N$ & $\begin{array}{l}\text { 영상을 출력할 때의 신호(Signal)와 잡음 } \\
\text { (Noise)을 의미하며, 수신된 영상에 잡음이 포 } \\
\text { 함되어 있을수록 출력영상이 찌그러지므로 잡음 } \\
\text { 수치가 낮은 영상을 평가함 }\end{array}$ \\
\hline & 해상도 & $\begin{array}{l}\text { 해상도는 화면 또는 촬영소자의 높이 방향으로, } \\
\text { 흑백의 무느가 몇 본까지 분해되는가를 분석하여 } \\
\text { 해상도의 성능을 평가함 }\end{array}$ \\
\hline
\end{tabular}

\subsection{4 위치인식 기술}

위치인식 기술의 평가는 기술이 U-Eco City에 적용될 때의 기능을 평가하는 부분과 위치인식 시스템 자체를 평가하는 부분으로 구분된다.

위치인식 시스템이 다양한 U-Eco City 서비스에 적용 되는 만큼 위치정보 파악의 정확성과 시스템의 적용성은 기술을 평가하는 주요 항목이며, 더불어 개인의 위치정 보를 활용한 시스템의 특성상 보안 역시 기술을 평가함 에 있어 배제될 수 없다[13]. 위치인식 시스템 자체를 평 가할 때에는 GPS와 위성을 이용하는 기술적 특성을 고 려하여 평가하며, 위치인식 시스템의 구현 속도와 오차 율, 수신기 성능, 신호 간편성 등이 이에 해당한다[21]. 
표 12. 위치인식기술의 2차 평가항목

\begin{tabular}{|l|l|}
\hline \multicolumn{1}{|c|}{ 항목 } & \multicolumn{1}{|c|}{ 개념 } \\
\hline 정확성 & $\begin{array}{l}\text { 위성신호를 이용하여 대상물의 위치정보를 정확하게 파 } \\
\text { 악할 수 있는지를 평가함 }\end{array}$ \\
\hline 적용성 & $\begin{array}{l}\text { 다양한 분야에 적용될 수 있는 환경 요건이 마련되어있 } \\
\text { 는지를 평가하며, 기반환경 구축여부를 측정함 }\end{array}$ \\
\hline 보안성 & $\begin{array}{l}\text { 위치정보 취득 시 개인의 위치정보가 타인에게 노출되지 } \\
\text { 않도록 하는 보안성에 대하여 평가함 }\end{array}$ \\
\hline 속도 & $\begin{array}{l}\text { 위치정보를 실시간으로 파악할 수 있는지를 평가하는 항 } \\
\text { 목이며, 대상물의 위치인식 속도를 측정함 }\end{array}$ \\
\hline 오차율 & $\begin{array}{l}\text { 수신에 있어 위치에 오차를 발생시킬 수 있는 요인(위성 } \\
\text { 궤도, 위성시계, 전리층 지연, 대류층 지연, 수신기 잡음 } \\
\text { 등)의 정도를 평가함 }\end{array}$ \\
\hline $\begin{array}{l}\text { 수 신 기 } \\
\text { 성능 }\end{array}$ & $\begin{array}{l}\text { Seamless 통신 빈도 수 등을 측정하여 GPS 수신기의 } \\
\text { 성능을 평가함 }\end{array}$ \\
\hline 신호 간 & $\begin{array}{l}\text { 현재 민간 사용자는 GPS에서 송신되는 2개의 신호 중 } \\
\text { 판송펑 넝 } 1 \text { (C/A코드)로만 접근이 가능하므로, 민간신호 } \\
\text { 의 간편성을 측정하여 활용성을 평가함 }\end{array}$ \\
\hline
\end{tabular}

\subsection{5 임베디드 S/W}

임베디드 $\mathrm{S} / \mathrm{W}$ 기술은 소프트웨어 자체를 평가하는 부 분과 구성요소를 평가하는 부분으로 구분하여 수행한다. 임베디드 소프웨어의 평가는 소프트웨어의 기술적 기능 을 평가하는 것으로써 하드웨어 사양에의 최적화율과 소 프트웨어의 실시간성, 신뢰도, 소형화 및 저전력 지원성 등이 이에 해당한다[17][24]. 임베디드 $\mathrm{S} / \mathrm{W}$ 의 구성요소 평가는 U-Eco City에 적용되는 소프트웨어에 대해 요구 되는 하드웨어 구현율, 하드웨어 적합성, 하드웨어 접근 성, 조건 만족성 등을 평가한다[12].

\section{표 13. 임베디드 $S / W$ 기술의 2 차 평가항목}

\begin{tabular}{|c|c|c|}
\hline \multicolumn{2}{|r|}{ 항목 } & 개념 \\
\hline \multirow{4}{*}{$\begin{array}{l}\text { ND } \\
\sum_{\text {평 }} \\
\text { 가 }\end{array}$} & $\begin{array}{l}\text { 하드 웨어 } \\
\text { 최적화 }\end{array}$ & $\begin{array}{l}\text { 용도에 부합하는 H/W에 내장될 수 있는지 여부 } \\
\text { 를 평가함 }\end{array}$ \\
\hline & 실시간성 & $\begin{array}{l}\text { 임베디드 S/W 시스템의 실시간 처리를 지원할 } \\
\text { 수 있는지 여부를 평가함 }\end{array}$ \\
\hline & 신뢰도 & $\begin{array}{l}\mathrm{S} / \mathrm{W} \text { 의 오류 및 오동작 등의 문제가 발생하지 않 } \\
\text { 도록 설계되어야 함 }\end{array}$ \\
\hline & $\begin{array}{l}\text { 소형화 및 } \\
\text { 저전력 }\end{array}$ & $\begin{array}{l}\text { 제품의 크기나 발열 등을 이유로 프로세서의 성 } \\
\text { 능 및 메모리 용량, } \mathrm{H} / \mathrm{W} \text { 내장가능 자원이 결정 } \\
\text { 되므로 경량화, 저전력성 등을 측정함 }\end{array}$ \\
\hline \multirow{4}{*}{$\begin{array}{l}\text { 오 } \\
\text { 구 } \\
\text { 궁 } \\
\text { ᄋ } \\
\text { 소 } \\
\text { 평 }\end{array}$} & $\begin{array}{l}\text { 운영체제 } \\
\text { 구현율 }\end{array}$ & $\begin{array}{l}\text { 임베디드 시스템의 구현성을 평가하는 항목으로 } \\
\text { 어플리케이션 기능의 구현에 필요한 OS 기능이 } \\
\text { 올바로 구현되는가를 측정함 }\end{array}$ \\
\hline & $\begin{array}{l}\text { 하드 웨어 } \\
\text { 적합성 }\end{array}$ & $\begin{array}{l}\text { 어플리케이션 기능 구현을 위한 하드웨어 접근코 } \\
\text { 드가 올바로 구현되었는지를 평가하는 항목임 }\end{array}$ \\
\hline & $\begin{array}{l}\text { 하드 웨어 } \\
\text { 접근성 }\end{array}$ & $\begin{array}{l}\text { 임베디드 시스템의 구현 체계 중 어플리케이션 } \\
\text { 기능에 특화된 구현 이외의 하드웨어 접근 코드 } \\
\text { 가 올바로 구현되었는가를 평가함 }\end{array}$ \\
\hline & $\begin{array}{l}\text { 조건 만족 } \\
\text { 성 }\end{array}$ & $\begin{array}{l}\text { 하드웨어를 추상화한 OS 계층을 위해 만족해야 } \\
\text { 할 조건에 따라 구현하였는가를 평가함 }\end{array}$ \\
\hline
\end{tabular}

\subsection{6 네트워크}

네트워크를 평가할 때에는 네트워크 시스템의 전반적 사항에 대하여 평가하는 것이 일반적이나, 개별적 상이 성을 지닌 시스템을 일괄 기준으로 평가하는 것은 합리 적이지 못하다. 따라서 본 연구에서는 문헌연구를 통해 네트워크 기술을 무선과 유선으로 구분하였으며, 무선네 트워크 기술의 경우 전송 거리에 따라 WPAN, WLAN, $\mathrm{WMAN}, \mathrm{WWAN}$ 으로 분류하고 이를 바탕으로 평가항 목을 도출하였다.

유선네트워크 기술은 FTTH/FTTP로 대표되며, 초고 속 인터넷 통신망의 구현을 목적으로 진보하고 있다. 유 선네트워크 기술의 목적은 가입자 가정에 데이터를 전송 하는 것이며, 안정적인 통신 보안성과 경제성을 우선적 으로 고려한다. 특히 최근의 유선통신망 이용자들은 $\mathrm{xDSL}$ 의 속도를 뛰어넘는 통신 속도를 요구하고 있으며 [3], 멀티미디어 시대의 도래로 인한 그래픽 기술의 발전 은 유선 네트워크 처리용량에 대한 요구수준을 높이고 있으므로 데이터 처리용량과 Seamless에 대한 고려는 필수적이라 할 수 있다. 반면 유선 네트워크가 고정된 기 지국을 바탕으로 서비스를 제공하고 있으므로 이동성을 지원하기 위한 항목(크기 및 무게 등)은 평가대상으로 고려되지 않는다는 특징이 있다.

$\mathrm{WPAN}$ 기술은 $20 \mathrm{~m}$ 이하의 짧은 거리에서 통신을 하 는 근거리 통신 기술이다. 따라서 WPAN 기술을 평가함 에 있어 전송거리 항목은 평가대상에서 제외할 수 있다. 반면 근거리 통신 기술로써의 효율성을 극대화하기 위해 서는 통신 속도와 전송 용량을 주요 평가항목으로 고려 해야하며, 데이터 고속 전송 시 Seamless가 보장되어야 한다. 또한 WPAN 단말기의 휴대성 지원을 위한 크기 및 무게, 저전력성 등이 주요 평가항목으로 대두된다. 이 밖에도 개인의 정보를 기반으로 통신을 수행하는 네트워 크 시스템이 기본적으로 갖춰야 할 보안성에 대한 평가 가 수행되어야 하며, 통신망 사용시의 경제성과 단말기 통합성 여부를 평가하는 것도 중요하다.

$\mathrm{WLAN}$ 기술은 거리 $100 \mathrm{~m}$ 이내의 지역에서 사용하는 무선 네트워크로써 $\mathrm{AP}$ (Access Point)를 활용하여 데이 터를 전송한다. 따라서 전송거리가 주요 평가항목으로 고려되어야 하며, 전송속도와 처리용량, 저전력성, 
Seamless, 크기 및 무게 등 네트워크 기술이 기본적으로 가져야 하는 항목에 대한 평가가 선행되어야 한다. 더불 어 일정 지역 내에서 대량의 데이터전송을 수행하는 시 스템의 특성상 데이터 송수신의 보안성과 경제성을 평가 할 수 있어야 하며, 다양한 표준이 존재하는 WLAN의 특성을 고려하여 시스템 표준화 여부 또한 평가해야 한 다.

$\mathrm{WMAN}$ 기술은 $\mathrm{LAN}$ 과 $\mathrm{WAN}$ 의 중간범위를 서비스하 는 통신망으로, $\mathrm{WLAN}$ 의 평가항목과 동일한 맥락으로 평가 가능하다. 다만 기존의 지점 간 통신 기술이나 교환 망 기술로는 점차 높아지는 고속통신에 대한 요구를 수 용할 수 없으므로, 타 네트워크 기술에 비해 통신 속도의 항목에 대한 비중이 크다 할 수 있다. 또한 $\mathrm{WMAN}$ 기술 중 최근 부각되는 Wibro의 경우 타 통신기술과는 달리 주파수 대역이 $2.3 \mathrm{GHz}$ 로 유료로 활용되고 있으므로, 기 술의 표준화여부가 주요 평가항목으로 고려된다.

WWAN 기술은 광대역 통신망으로 불리며, 일반적으 로 여러 행정구역이나 국가, 또는 국가 간의 경계를 넘어 사용되는 이동통신 기술로 대표된다. 따라서 네트워크 기술이 지녀야하는 기본적 기능을 갖춤과 동시에 이동성 을 지원하는지 여부를 주요하게 평가해야 한다.

\section{표 14. 네트워크기술의 2차 평가항목}

\begin{tabular}{|c|c|c|}
\hline \multicolumn{2}{|c|}{ 항목 } & 개념 \\
\hline \multicolumn{2}{|c|}{ 유선 } & 보안성, 경제성, 전송속도, Seamless, 처리용량 \\
\hline \multirow[t]{4}{*}{ 문 } & $\begin{array}{l}\text { WPA } \\
\text { N }\end{array}$ & $\begin{array}{l}\text { 전송속도, Seamless,저전력성, 크기 및 무게, 보안 } \\
\text { 성, 경제성, 처리용량, 단말기 통합성 }\end{array}$ \\
\hline & $\begin{array}{l}\text { WLA } \\
\text { N }\end{array}$ & $\begin{array}{l}\text { 전송거리, 전송속도, 표준화여부, Seamless, 저전 } \\
\text { 력성, 크기 및 무게, 보안성, 경제성, 처리용량, 단말 } \\
\text { 기 통합성 }\end{array}$ \\
\hline & $\begin{array}{l}\text { W M } \\
\text { AN }\end{array}$ & $\begin{array}{l}\text { 전송거리, 전송속도, 표준화여부, Seamless, 저전 } \\
\text { 력성, 크기 및 무게, 보안성, 경제성, 처리용량, 단말 } \\
\text { 기 통합성 }\end{array}$ \\
\hline & $\begin{array}{l}\text { W W } \\
\text { AN }\end{array}$ & $\begin{array}{l}\text { 전송거리, 전송속도, Seamless, 저전력성, 크기 및 } \\
\text { 무게, 보안성, 경제성, 처리용량, 단말기 통합성 }\end{array}$ \\
\hline
\end{tabular}

\section{3 주기율표 도출을 통한 동태적 평가항목 도출}

본 연구는 U-Eco City 분야별 핵심 기술의 평가항목 도출을 목적으로 한다. 이를 위하여 기술의 진화과정을 통해 대두되는 이슈들을 검토하여 분야별 기술의 1 차 평 가항목을 도출하였고, 문헌연구를 실시하여 U-Eco City 핵심기술이 갖춰야 하는 본연의 기능을 갖추었는지 여부
를 검토 - 보완함으로써 U-Eco City 기술의 2차 평가항 목을 도출하였다.

앞서 도출된 1,2 차 평가항목은 기술이 지녀야할 기본 적 특성과 기술의 진화과정에서 대두되는 쟁점을 고려한 것으로써, 현재의 U-Eco City 기술을 평가하기에는 부 족함이 없어 보인다. 그러나 U-Eco City는 미래형 첨단 도시를 표방하며 다양한 신기술과 융합기술의 도입을 목 적으로 하고 있으므로 현재의 기술수준에 맞춰진 기술평 가는 U-Eco City 기술의 적용 - 선정을 위한 판단 근거 로 활용할 수 없다. 기술평가는 산재하는 수많은 요소 중 주요하다 여겨지는 항목을 중심으로 이루어지며, 이러한 항목의 중요도는 해당기술의 발전 방향에 따라 변화하기 때문이다. 따라서 기술적 특성과 개별 기술의 기본기능 을 평가하는 항목과 더불어 시간의 흐름에 따른 기술개 발 방향성을 탐지할 수 있는 평가항목의 보완이 필요하 며, 본 연구에서는 이를 동태적 평가항목으로 정의한다.

$\mathrm{U}-\mathrm{Eco}$ City 기술의 동태적 평가는 전술한 바와 같이 기술개발의 방향성 탐지를 기본으로 하며, 향후 개발될 기술을 현실적으로 평가할 수 있는 평가항목 도출을 목 적으로 한다. 이를 위해 본 연구에서는 원소주기율표의 기능에 착안하여 기술주기율표를 구축하였으며, U-Eco City 기술의 동태적 평가항목 도출에 활용하였다.

원소주기율표는 개별 원소의 특성을 바탕으로 원소를 배열한 것으로써 초기에 관찰된 단순형 원소배열에 비슷 한 성질의 원소들이 추가적으로 발견됨에 따라 일정한 주기성을 중심으로 원소가 배열됨을 증명한 표이다. 원 소주기율표는 시간이 지남에 따라 융합원소의 발견 및 미발견 원소를 예측하는데 활용되었으며, 본 연구에서는 원소주기율표의 미발견원소의 예측 기능에 착안하여 각 기술의 특성에 해당하는 항목을 두 축으로 배열하고 분 야별 요소기술의 특징 및 발전방향을 파악함으로써 핵심 기술의 주기성을 발견하고 향후 개발기술의 주안점을 예 측하고자 하였다. 또한 기술별로 예측된 주기성을 토대 로 향후 개발될 기술의 쟁점이 되는 항목을 동태적 평가 항목으로 정의함으로써 앞서 제기한 문제점 -시간의 흐 름에 따라 변화하는 기술적 특성을 평가할 수 있는 항목 보완- 을 해결코자 하였다. 기술주기율표 구축은 U-Eco City 핵심기술을 대상으로 실시되며, U-Eco City 핵심 


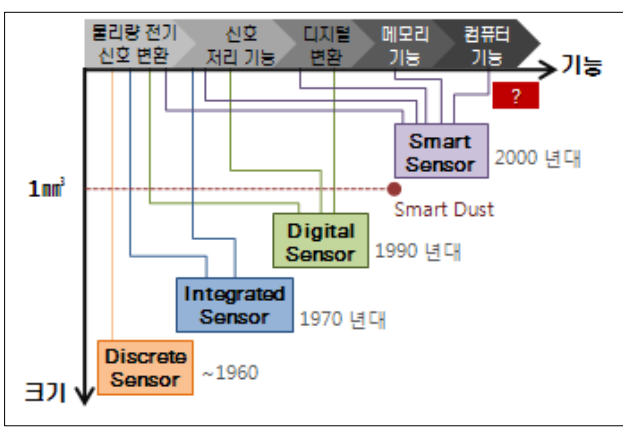

그림 8. 일반 센서 기술주기율표

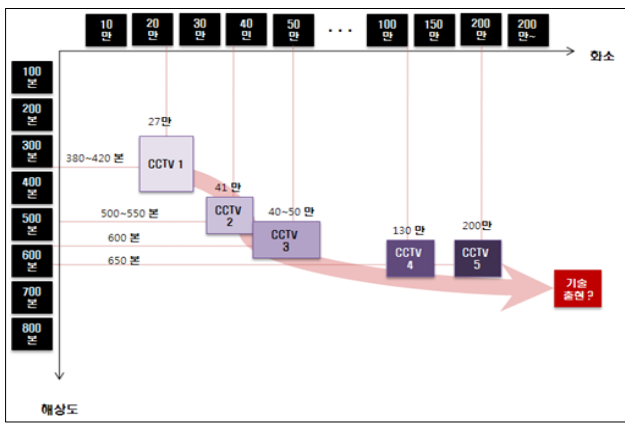

그림 10. 영상인지 기술주기율표

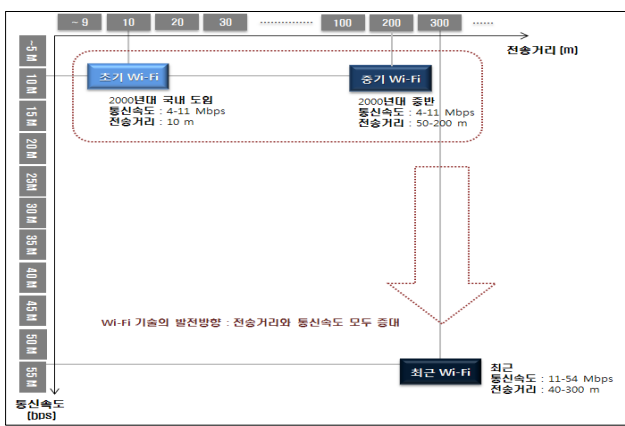

그림 13. WLAN 기술주기율표

기술에는 앞서 평가대상 기술의 범위에서 선정한 정보수 집기술(센싱 : 일반센서, 상황인지기술, 영상인지기술)과 정보가공기술(임베디드 $\mathrm{S} / \mathrm{W}$ 기술) 정보활용기술(네트 워크 기술) 등이 해당한다.

\subsection{1 일반 센서 기술의 동태적 평가항목}

일반 센서 기술은 1960 년대 등장 이후 다양한 기능이 추가-집적되는 것으로 나타났으며 센서의 크기감소를 중심으로 발전하는 것으로 조사되었다.

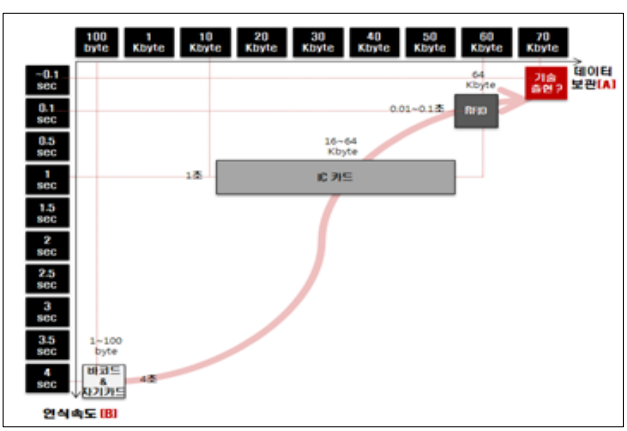

그림 9. 상황인지 기술주기율표

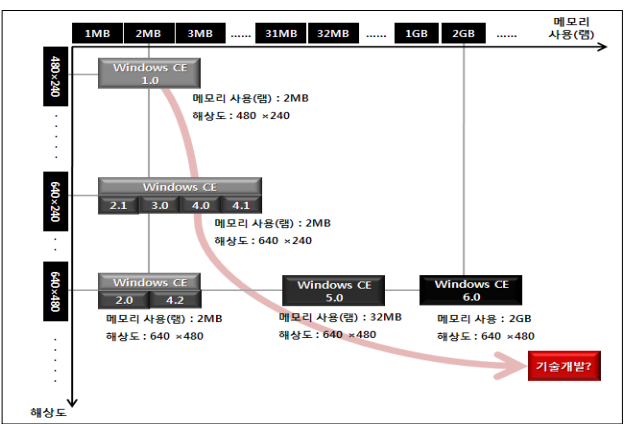

그림 11. 임베디드S/W 기술주기율표

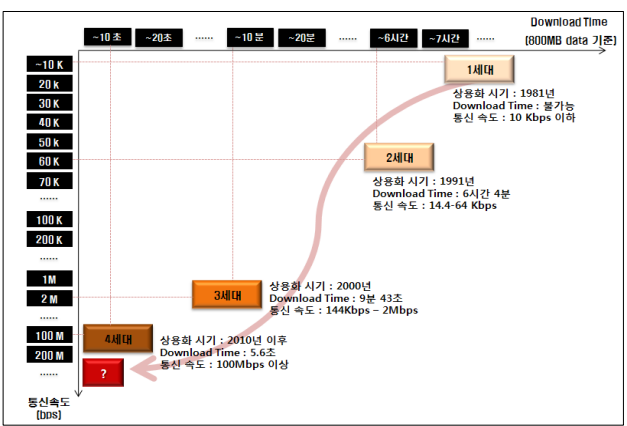

그림 14. WWAN 기술주기율표

센서기술의 개척기라 할 수 있었던 1960년대에는 여러 가지 물리현상을 전기신호로 변환하기 위한 다양한 연구 가 수행되었고, 결과 다양한 기능-온도, 압력, 가속도 등 -을 수행하는 디스크리트 센서가 개발되었다. 1970년대 에는 센서 및 구동장치 등을 소형화 - 복합화를 중심으로 기술이 발전하며 집적 센서를 탄생시켰으며, 이후 센싱 소자를 통해 계측된 아날로그 정보를 디지털 방식으로 보정할 수 있는 디지털 센서가 개발되었다. 디지털 센서 의 개발은 과거 크기의 감소에만 집중되던 센서관련 기 
술이 기능의 복합화를 중심으로 이루어지고 있음을 뜻한 다. 1990년대에는 센서 칩 위에 컴퓨터가 내장되면서 다 양한 기능이 가능한 지능형 센서가 탄생하였고, 최근에 는 소비전력 감소와 비용절감, 단일 센서의 고기능화에 기술개발이 집중되면서 스마트 더스트와 같은 극소형 센 서가 개발되는 등 센서기술은 기능의 다양화와 초소형 초경량화를 중심으로 발전하고 있다[그림 8].

\section{표 15. 일반 센서 기술의 발전}

\begin{tabular}{|l|l|l|}
\hline \multicolumn{1}{|c|}{ 구분 } & \multicolumn{1}{|c|}{ 기능 } & \multirow{2}{*}{ 크기 } \\
\cline { 1 - 2 } 1960년 & 물리량 계측 & \\
\hline 1970년대 & 물리량 계측, 신호처리 기능 \\
\hline 1990년대 & 물리량 계측, 신호처리, 정보전송 & $1 \mathrm{~mm}^{3}$ \\
\cline { 1 - 2 } 2000년 이후 & $\begin{array}{l}\text { 물리량 계측, 신호처리, 정보전송, 저장. } \\
\text { 제어 }\end{array}$ & $1 \mathrm{~mm}^{3}$ 이하 \\
\hline \multirow{2}{*}{ 향후 출현기술 } & $\begin{array}{l}\text { 컴퓨터 기능, 셀프모니터링 기능, (다양 } \\
\text { 한 기능 추가) }\end{array}$ & $1 \mathrm{~mm}^{3}$ 이하 \\
\hline
\end{tabular}

\subsection{2 상황인지 기술의 동태적 평가항목}

상황인지 기술은 바코드, 자기카드, IC카드, $\mathrm{RFID}$ 를 중심으로 발전하고 있으며, 본 연구에서는 인식 속도와 인식률, 데이터 보관량을 중심으로 동태적 평가항목을 도출하였다.

\section{표 16. 상황인지 기술의 발전}

\begin{tabular}{|c|c|c|c|c|}
\hline \multirow{2}{*}{ 구분 } & \multicolumn{2}{|c|}{$\sim 2000$ 년 } & $\begin{array}{c}2000 \text { 년대 } \\
\text { 이후 }\end{array}$ & $\begin{array}{c}\text { 향후 } \\
\text { 출현기술 }\end{array}$ \\
\cline { 2 - 5 } & 바코드 & 자기카드 & IC카드 & RFID \\
\hline 인식률 & $\begin{array}{c}95 \% \\
\text { 0하하 }\end{array}$ & $\begin{array}{c}99.9 \% \\
\text { 이상 }\end{array}$ & $\begin{array}{c}99.9 \% \\
\text { 0|상 }\end{array}$ & $99.9 \%$ 이상 \\
\hline $\begin{array}{c}\text { 인식 } \\
\text { 속도 }\end{array}$ & 4 초 & 1 초 & $0.1 \sim 1$ 초 & $\begin{array}{c}0.01 \text { 초 } \\
\text { 이하 }\end{array}$ \\
\hline $\begin{array}{c}\text { 데이터 } \\
\text { 보관량 }\end{array}$ & $\begin{array}{c}1 \sim 100 \\
\text { (byte) }\end{array}$ & $\begin{array}{c}1 \sim 100 \\
\text { (byte) }\end{array}$ & $\begin{array}{c}16-64 \\
\text { (Kbyte) }\end{array}$ & $\begin{array}{c}64 \mathrm{Kbyte} \\
\text { 이상 }\end{array}$ \\
\hline
\end{tabular}

바코드로 대표되는 초기의 상황인지 기술의 인식률은 $95 \%$ 까지 대상을 인식할 수 있었으며, 자기카드 개발 이 후에는 $99.9 \%$ 까지 상황을 인지할 수 있는 기술이 개발되 어 2000년대 초반에 이미 기술개발 완료 단계에 도달한 것으로 조사되었다. 반면 과거 4초대에 머무르던 상황인 지 기술의 인식속도는 2000년대 이후 0.01초로 급격히 감소한 것으로 나타났으며 $\mathrm{RFID}$ 출현 이후 0.01 초 이하
의 속도로 인식이 가능해진 것으로 조사되었다. 상황인 지 기술의 데이터 보관량은 2000년대 초반 $100 \mathrm{byte}$ 에서 2000년대 후반 $64 \mathrm{Kbyte}$ 로 기술발전이 이루어지는 것으 로 조사되었으며 $\mathrm{RFID}$ 출현 이후에는 $64 \mathrm{Kbyte}$ 보관량 이 증가하는 것으로 나타났다[그림 9].

\subsection{3 영상인지 기술의 동태적 평가항목}

영상인지 기술의 평가항목은 $\mathrm{CCTV}$ 를 중심으로 도출 하였으며, 기술개발의 쟁점이라 할 수 있는 해상도와 회 전력, 화소정보를 탐색하였다.

\section{표 17. 영상인지 기술의 발전}

\begin{tabular}{|c|c|c|c|c|c|}
\hline 구분 & $1980-1990$ & $\begin{array}{c}\text { 2000년대 } \\
\text { 이후 }\end{array}$ & \multicolumn{3}{|c|}{ 2009년 이후 } \\
\hline $\begin{array}{c}\text { 해상도 } \\
\text { (본) }\end{array}$ & $380-420$ & $500-550$ & 600 & 650 & 650 \\
\hline 회전력 & $360^{\circ}$ 미만 & $360^{\circ}$ & $360^{\circ}$ & $360^{\circ}$ & $360^{\circ}$ \\
\hline 화소 & 27 만 & 41 만 & $40-50$ 만 & 130 만 & 200 만 \\
\hline
\end{tabular}

초기의 CCTV는 1980 년대 테러감시를 목적으로 아일 랜드 공화국에서 설치한 것이 그 시초로써, 27 만 화소에 해상도 380 420본으로 피사체의 윤곽이 흐릿하게 표현 되었으며 회전각도가 $360^{\circ}$ 미만으로, 촬영 가능한 영상의 범위가 제한적이었다. 2001년 전후를 기점으로 CCTV의 아날로그 녹화방식이 디지털 방식으로 전환되면서 해상 도 성능이 550본 까지 증가하고, 화소 또한 기존 $\mathrm{CCTV}$ 에 비해 1.5 배 개선된 41 만 화소로 기술개발이 진행되었 으며 $360^{\circ}$ 회전이 가능해 지는 등 영상인지 기술의 전반 적 기술혁신이 이루어졌다. 최근에는 메가픽셀의 영상을 지원하는 $\mathrm{HD}-\mathrm{CCTV}$ 가 등장하면서 기존 카메라의 해상 도 한계를 뛰어넘는 고해상도 디지털 화질을 제공하고 있다[그림 10].

\subsection{4 임베디드 $S / W$ 의 동태적 평가항목}

임베디드 $\mathrm{S} / \mathrm{W}$ 기술은 현재 가장 많이 활용되는 Windows $\mathrm{CE}$ 를 중심으로 기술의 발전을 검토하였으며, 이를 바탕으로 기술주기율표를 구축한 후 동태적 평가항 목을 도출하였다.

초기의 Windows $\mathrm{CE}$ 는 메모리사용평균 $2 \mathrm{MB}$, 구현가 
능 해상도 $480 \times 240$ 의 매우 낮은 형태의 프로그램이었으 며, 단순한 형태의 PDA 운영체제에 주로 사용되었다. 2000년대 중반에 들어서며 메모리 사용평균 기술과 시스 템 프로세스 기술이 발달하여 빠른 속도의 프로그램 처 리를 지원할 수 있게 되었고, 2000년대 후반에는 임베디 드 $\mathrm{S} / \mathrm{W}$ 기술의 급진적 발전이 진행되어 프로그램의 실 시간 처리가 가능하게 되었다[그림 11].

\section{표 18. 임베디드 S/W 기술의 발전}

\begin{tabular}{|c|c|c|c|c|c|c|}
\hline 구분 & 1996 & 1997 & \multicolumn{3}{|c|}{ 2000년대 이후 } & $\begin{array}{c}\text { 향후 } \\
\text { 출현기술 }\end{array}$ \\
\hline 메모리 사용 & $2 \mathrm{MB}$ & $2 \mathrm{MB}$ & $2 \mathrm{MB}$ & $32 \mathrm{MB}$ & $2 \mathrm{~GB}$ & $2 \mathrm{MB}$ 이상 \\
\hline 해상도 & $\begin{array}{c}480 \times \\
240\end{array}$ & $\begin{array}{c}640 \times \\
240\end{array}$ & $\begin{array}{c}640 \times \\
480\end{array}$ & $\begin{array}{c}640 \times \\
480\end{array}$ & $\begin{array}{c}640 \times \\
480\end{array}$ & $\begin{array}{c}640 \times 480 \\
\text { 이상 }\end{array}$ \\
\hline $\begin{array}{c}\text { 시스템 } \\
\text { 프로세스 }\end{array}$ & \multicolumn{3}{|c|}{32 개 이하 } & 32 개 & 3.2 만 & $\begin{array}{c}\text { 3.2만개 } \\
\text { 이상 }\end{array}$ \\
\hline
\end{tabular}

기술발전의 추이를 바탕으로 살펴본 결과, 향후에는 시스템 프로세스 수준이 높고 메모리 사용평균이 큰 임
베디드 $\mathrm{S} / \mathrm{W}$ 에 대한 수요가 높을 것으로 판단되며 구현 가능한 해상도를 중심으로 기술발전이 이루어지리라 예 상된다.

\subsection{5 네트워크의 동태적 평가항목}

네트워크 시스템은 전송거리에 따라 응용되는 기술이 차별화되므로, 각 네트워크 시스템의 기술주기율표를 개 별적으로 구축하고 이를 바탕으로 동태적 평가항목을 도 출하였다. 다만 $\mathrm{WMAN}$ 은 기술적 특징과 발전 과정에 있어 WLAN 기술과 유사성을 보이고 있으므로 개별적 으로 기술주기율표를 구축하거나 동태적 평가항목을 도 출하지는 않았다.

표 19. WPAN 기술의 발전

\begin{tabular}{|c|c|c|c|c|c|c|}
\hline 구분 & 1990 & 2004 & 2006 & 2007 & 2009 & $\begin{array}{c}\text { 향후 } \\
\text { 출현기술 }\end{array}$ \\
\hline 통신속도 & $723 \mathrm{Kbps}$ & $2.1 \mathrm{Mbps}$ & $2.1 \mathrm{Mbps}$ & $12 \mathrm{Mbps}$ & $24 \mathrm{Mbps}$ & $\begin{array}{c}24 \mathrm{Mbps} \\
\text { 이상 }\end{array}$ \\
\hline 전송거리 & $30 \mathrm{~m}$ 이하 & $30 \mathrm{~m}$ & $75 \mathrm{~m}$ & $100 \mathrm{~m}$ & $100 \mathrm{~m}$ & $100 \mathrm{~m}$ 이상 \\
\hline
\end{tabular}

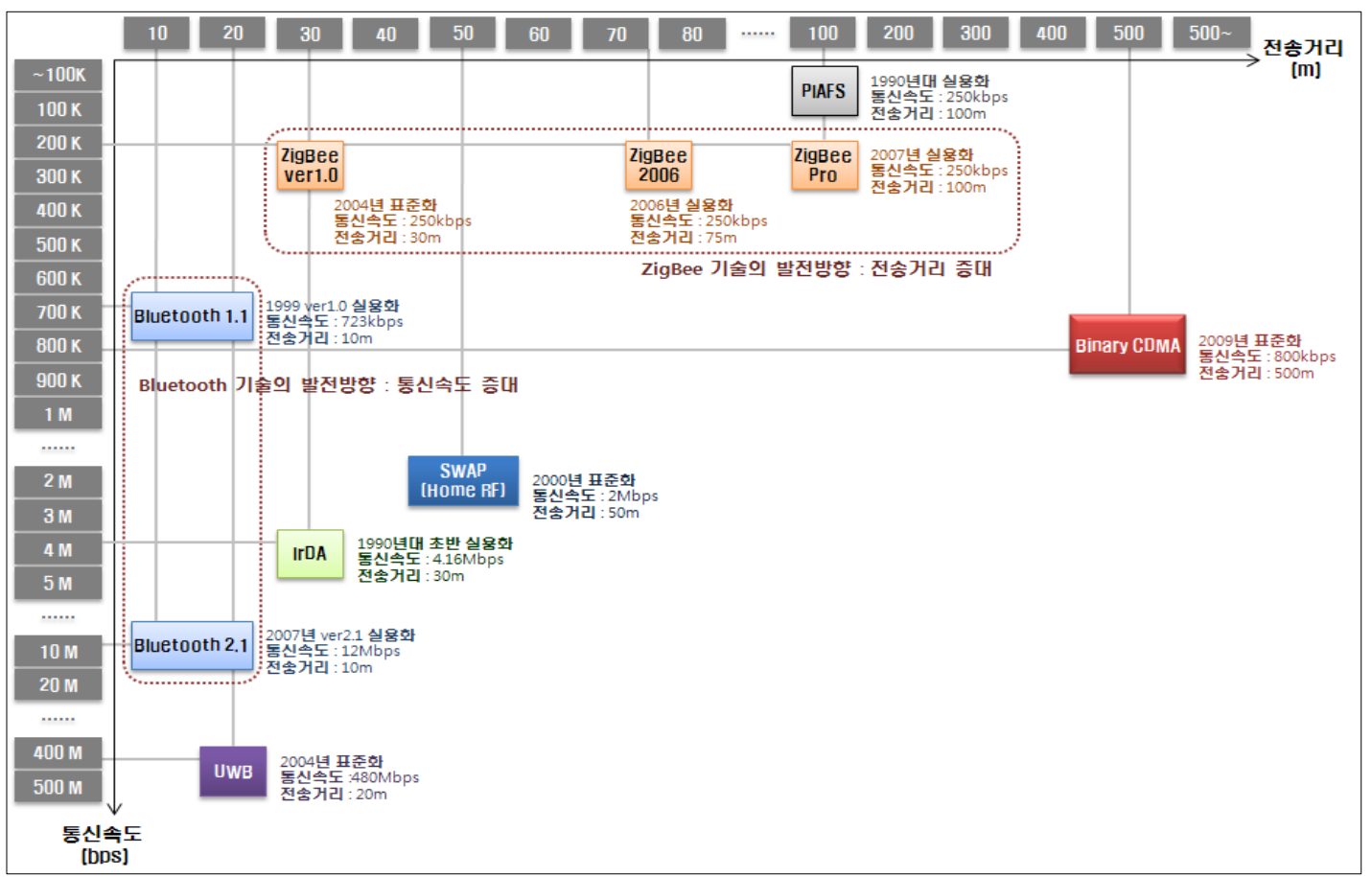


먼저 WPAN 기술의 동태적 평가항목 도출을 위하여 ZigBee, Bluetooth, PIAFS, IrDA, UWB, SWAP, Bnary $\mathrm{CDMA}$ 등을 검토하였으며 본 연구에서는 $\mathrm{WPAN}$ 기술 중 가장 많이 활용되고 있는 Bluetooth과 ZigBee 기술을 중심으로 동태적 평가항목을 도출하였다. Bluetooth 기 술은 근거리 무선통신을 위하여 개발된 기술로써 전송거 리가 $10 \mathrm{~m}$ 를 넘지 않는 한도 내에서 활용되므로, 전송속 도의 향상을 목표로 기술개발이 진행되고 있다. 반면 $\mathrm{ZigBee}$ 기술은 통신 속도가 250Kbps로 고정된 상태에서 전송거리의 확대를 중심으로 기술개발이 진행되고 있는 것으로 나타났다[그림 12].

$\mathrm{WLAN}$ 기술은 WPAN과 마찬가지로 전송거리와 통 신 속도를 중심으로 기술개발이 진행되고 있으며, 본 연 구에서는 WLAN 기술의 동태적 평가항목 도출을 위하 여 $\mathrm{Wi}-\mathrm{Fi}$ 를 대상으로 기술주기율표를 구축하였다[그림 13].

\section{표 20. WLAN 기술의 발전}

\begin{tabular}{|c|c|c|c|c|}
\hline 구분 & 2000 년대 & $\begin{array}{c}2000 \text { 년대 } \\
\text { 중반 }\end{array}$ & 2009년 현재 & 향후 출현기술 \\
\hline 통신속도 & $4-11 \mathrm{Mbps}$ & $4-11 \mathrm{Mbps}$ & $11-54 \mathrm{Mbps}$ & $54 \mathrm{Mbps}$ 이상 \\
\hline 전송거리 & $10 \mathrm{~m}$ & $50-200 \mathrm{~m}$ & $40-300 \mathrm{~m}$ & $300 \mathrm{~m}$ 이상 \\
\hline
\end{tabular}

초기 $\mathrm{Wi}-\mathrm{Fi}$ 기술의 전송거리는 $10 \mathrm{~m}$ 로, 근거리 무선통 신 기술과 별다른 차이가 없었으나, 기술개발에 따라 점 차 증가하여 2000년대 중반에는 50-200m까지 전송거리 가 확대되었으며, 2009년 현재 최소 $40 \mathrm{~m}$ 에서 최대 $300 \mathrm{~m}$ 까지 그 범위가 증가하였다. 통신 속도는 2000년대 초반 최대 $11 \mathrm{Mbps}$ 에서 2009년 현재 54Mbps까지 빨라졌으며, 향후에는 그 이상의 기술개발이 이루어질 것으로 예상된다.

WWAN 기술은 이동통신 기술로 대표되며, 본 연구에 서는 WWAN 기술의 세대별 특징을 파악하고 이를 토대 로 기술주기율표를 구축한 후 동태적 평가항목을 도출하 였다[그림 14].

이동통신 기술로 대표되는 WWAN 기술은 여타의 네 트워크 기술과는 달리 국제적 표준이 정해져 있어 다양 한 대체 기술이 존재하지는 않으나, 국제 표준이 확정되 기 전까지 다양한 기능구현을 목적으로 성능개선이 이루
어지고 있으므로, 이를 바탕으로 기술개발의 방향성을 탐색할 수 있었다. WWAN 이동통신 기술의 세대별 기 술을 살펴본 결과 도출된 기술개발의 주안점은 통신 속 도와 Data Download Time(DDT, $800 \mathrm{MB}$ 기준)으로써, 속도의 향상과 처리시간 감소를 중심으로 기술발전이 이 루어지는 것으로 나타났다.

\section{표 21. WWAN 기술의 발전}

\begin{tabular}{|c|c|c|c|c|}
\hline 구분 & 1세대 & 2세대 & 3세대 & 4세대 \\
\hline 표준기술 & $\begin{array}{c}\text { AMPS, } \\
\text { TACS, NMT } \\
\text { 아날로그통신 }\end{array}$ & $\begin{array}{c}\text { TDMA, } \\
\text { CDMA, } \\
\text { GSM, PDC }\end{array}$ & $\begin{array}{c}\text { Wibro, } \\
\text { W-CDMA }\end{array}$ & $\begin{array}{c}\text { 2010표준 } \\
\text { 확정예정 }\end{array}$ \\
\hline 통신속도 & 10Kbps 이하 & $\begin{array}{c}14.4-64 \mathrm{~Kb} \\
\text { ps }\end{array}$ & $\begin{array}{c}\text { 144Kbps- } \\
\text { 2Mbps }\end{array}$ & $\begin{array}{c}\text { 100Mbps } \\
\text { 이상 }\end{array}$ \\
\hline 상용화 시기 & 1981년 & 1991년 & 2000년 & 2010년 이후 \\
\hline DDT & 불가능 & 6시간 4분 & 9분 43초 & 5.6초 \\
\hline
\end{tabular}

본 연구에서는 앞서 도출된 $1 \cdot 2$ 차 평가항목과 더불어 기술개발의 동향을 검토하여 분야별 기술의 방향성을 탐 색할 수 있는 동태적 평가항목을 도출하였으며, 이는 향 후 개발될 기술의 수준을 분야별로 예측하고 이를 평가 할 수 있는 기반 연구라는 점에서 그 의의가 있다. 동태 적 평가항목은 개별 분야의 기술주기율표 작성을 토대로 도출되며, 기술 주기율표는 각 기술이 어떠한 양상으로 진화하고 있는지를 살펴보고 이들의 방향성 탐지 및 주 안점 예측을 수행함으로써 구축된다.

동태적 평가항목 도출의 결과는 표22와 같으며, 도출 된 결과는 앞서 구축된 $1 \cdot 2$ 차 평가항목과 통합되어 U-Eco City 기술평가에 활용 가능하다.

\section{표 22. 동태적 평가항목 종합}

\begin{tabular}{|c|c|c|}
\hline \multicolumn{2}{|c|}{ 평가항목 } & 개념 \\
\hline \multicolumn{2}{|c|}{ 일반 센서 } & 센서의 크기(소형화), 센서의 다기능화 \\
\hline \multicolumn{2}{|c|}{ 상황인지기술 } & 인식률, 인식 속도, 데이터 보관량, \\
\hline \multicolumn{2}{|c|}{ 영상인지기술 } & 해상도, 회전력, 화소 \\
\hline \multicolumn{2}{|c|}{ 임베디드S/W기술 } & 메모리 사용 평균, 프로세스 시간 \\
\hline \multirow{3}{*}{$\begin{array}{l}\text { 네트워 } \\
\text { 크 기 } \\
\text { 술 }\end{array}$} & WPAN & 전송속도, 전송거리 \\
\hline & WLAN & 전송속도, 전송거리 \\
\hline & WWAN & 전송속도, Data Download Time \\
\hline
\end{tabular}




\section{표 23. U-Eco City 기술의 최종 평가항목}

\begin{tabular}{|c|c|c|}
\hline \multicolumn{2}{|c|}{ 2차 평가항목 } & 개념 \\
\hline \multicolumn{2}{|c|}{ 일반 센서 } & 집적화, 복합다기능화, 분해능, 감도, 선형성, 범위, 응답시간, 신뢰성, 정확성, 반복정밀도, 크기, 무게, 전력 \\
\hline \multicolumn{2}{|c|}{ 상황인지 기술 } & $\begin{array}{l}\text { 인식거리, 인식속도, 수명, 데이타메모리 용량, 읽가쓰기능, 전력공급방식, 주파수, 인식률, 전력소모량, 충돌방지성, 태그가격, } \\
\text { 크기, 멀티주파수 대응성, 인식률 }\end{array}$ \\
\hline \multicolumn{2}{|c|}{ 영상인지 기술 } & 전송거리, 화질, 실시간성, 다기능성, $f$ Number, 초점거리, 화각, 화소 수, 유효 화소 수, $\mathrm{S} / \mathrm{N}$, 해상도, 회전력 \\
\hline \multicolumn{2}{|c|}{ 위치인식 기술 } & 좌표 정확도, 정보 보안성, 적용성, 속도, 오차율, 수신기 성능, 신호 간편성 \\
\hline \multicolumn{2}{|c|}{ 임베디드 $S / W$ 기술 } & $\begin{array}{l}\text { 처리용량, 호환성, 속도, 실시간성, 라이센스, 신뢰도, 소형화, 저전력성, 운영체제 구현율, 하드웨어 적합성, 하드웨어 접근성, } \\
\text { 조건 만족성, 메모리 사용평균, 프로세스 시간 }\end{array}$ \\
\hline \multirow{5}{*}{$\begin{array}{l}\text { 네 트 } \\
\text { 워 크 } \\
\text { 기술 }\end{array}$} & 유선 & 보안성, 경제성, 전송속도, Seamless, 처리용량 \\
\hline & WPAN & 전송거리, 전송속도, 처리용량, Seamless, 저전력성, 크기 및 무게, 보안성, 경제성,단말기 통합성 \\
\hline & WLAN & 전송거리, 전송속도, 처리용량, 표준화여부, Seamless, 저전력성, 크기 및 무게, 보안성, 경제성,단말기 통합성 \\
\hline & WMAN & 전송거리, 전송속도, 처리용량, 표준화여부, Seamless, 저전력성, 크기 및 무게, 보안성, 경제성, 단말기 통합성 \\
\hline & WWAN & 전송거리, 전송속도, 처리용량, Seamless, 저전력성, 크기 및 무게, 보안성, 경제성, 단말기 통합성, Data Download Time \\
\hline
\end{tabular}

\section{4. 결론}

U-Eco City 기술을 평가할 수 있는 표준화된 평가항 목의 부재는 무분별한 기술적용과 기술개발의 중복투자 등의 문제를 야기하며, 지자체간 연계부족 및 신도시 구 축사업의 예산 낭비 등 국가적 문제를 초래할 수 있다. 또한 적용되는 개별 기술의 질적 측면에 대한 평가가 선 행되지 않은 채 기술이 적용될 경우 구현되는 서비스의 질을 저하시킬 뿐 아니라, 도시 자체의 수준을 격하시킬 우려가 있다.

이에 본 연구에서는 U-Eco City에 적용 가능한 기술 을 다양한 측면에서 검토하고, 개별 기술의 진화과정을 살펴봄으로써 U-Eco City에 적용되는 기술이 갖추어야 할 요건을 장기적 관점에서 평가할 수 있는 항목을 구축 하였다. 기술평가항목 도출의 $1 \cdot 2$ 차 단계에서는 분야별 기술의 기본적 성능을 평가할 수 있는 항목을 도출하였 으며, 이는 일반 기술이 아닌 U-Eco City 적용기술을 평 가할 수 있는 차별화된 체계를 구축하였다는데 그 의의 가 있다. 또한 미래의 기술을 예측할 수 있는 주기율표의 개념을 활용하고, 이를 바탕으로 U-Eco City에 적용되 는 분야별 기술의 진화과정에서 대두되는 특성을 고려한 점은 기존의 경직된 연구와는 차별화된 본 연구만의 특 징이라 할 수 있다.

물론 본 연구를 통해 도출된 평가항목은 분야별 기술 의 성능적 측면을 고찰하고 장기적으로 활용 가능한 평
가항목을 도출해냈다는 장점이 있으나, 실제 도시에서 어떻게 적용될 것인지 검증된 바 없으며, 적용 기술을 평 가하는 방법론에 따라 평가지표가 달라질 수 있기에, 실 제 도시에 적용되는 기술을 평가할 때 본 연구에서 도출 된 지표들이 얼마나 의미 있게 활용될 수 있는가에 대해 서는 파악하기 어렵다는 한계가 있을 수 있다. 따라서 향 후에는 U-Eco City 적용기술의 평가방법을 고찰하고 적 절한 평가방법을 구축함으로써 본 연구에서 도출된 평가 항목이 얼마나 적절한지를 검토함은 물론 실제 사례연구 를 통해 U-Eco City 기술평가에의 적용 가능성을 검증 하는 후속연구가 진행되어야 할 것이다.

U-Eco City는 도시민의 편의를 위한 다양한 서비스가 공간차원에 적용된 미래지향적 도시이며, 성공적인 U-Eco City의 구현을 위해서는 구현되는 서비스의 질 향상이 필수적으로 수반되어야 한다. 이에 본 연구에서 도출된 평가항목이 U-Eco City 기술적용 과정에 도입된 다면, 기술적용의 객관성 확보는 물론 최적의 기술을 서 비스에 도입할 수 있는 기제로 작용함으로써 U-Eco City의 성공적 구현을 위한 밑거름이 될 것이다. 객관적 평가지표를 바탕으로 U-Eco City 전 기술의 적용가능성 이 평가되고, 이를 바탕으로 U-Eco City의 서비스가 구 현된다면 도시차원의 질 향상은 물론 도시민의 삶에 대 한 만족도 향상까지도 기대할 수 있을 것이다. U-Eco City는 단순히 다양한 IT 기술이 도입된 최첨단 도시로 서의 의미만을 내포하지 않는다. 도시는 사람이 살고 있 
는 정주의 기반이며 U-Eco City의 성패는 해당 도시민 의 삶과 직결된다 해도 과언이 아닐 것이다. 이에 본 연 구에서 제시하고 있는 U-Eco City 기술평가항목은 U-Eco City에서 구현되는 다양한 서비스의 적용기술을 객관적으로 평가할 수 있는 기본 틀이 될 것이며, 이는 전체 서비스의 질 향상은 물론 도시 전반의 삶의 질 향상 과 U-Eco City 건설의 표준체계 확립에 이바지할 수 있 을 것으로 판단된다.

\section{참 고 문 헌}

[1] 강영옥, "U-Eco City 구축 가이드라인 작성을 위 한 기초연구”, 한국공간정보시스템학회논문지, 제 11권, 제2호, pp.170-176, 2009.

[2] 국토해양부, "유비쿼터스도시의 건설 등에 관한 법 률”, 2008.

[3] 권정국, 유제훈, 김봉태, 이상호, "FTTH E-PON 시스템의 TPS 성능 평가”, 한국정보과학회 정보 과학논문지, 제34권, 제6호, pp.525-532, 2009.

[4] 김복환, 구지희, 곽인영, "지속가능한 U-City 운영 을 위한 선순환 U-City모델의 개발방향 연구”, 한 국공간정보시스템학회지, 제 11 권, 제 1 호, pp.145-156, 2009.

[5] 김은형, "지능형 도시공간정보 서비스 표준체계에 관한 연구”, 한국GIS학회 2008 공동 춘계학술대회 발표논문, pp.238-247, 2008.

[6] 김지현, 김호기, 정창무, "기술진화 계통도를 이용 한 U-City 기술의 분류”, 국토계획, 제45권, 제 1 호, pp.223-236, 2010.

[7] 김지현, 정창무, "유비쿼터스 도시 적용기술 평가 를 위한 표준화 방안 연구”, 대한국토도시계획학 회 춘계학술대회 발표논문, pp.129-137, 2009.

[8] 박승창, 남상엽, 류영달, 이기혁, 김완석, 유비쿼터 스 센서 네트워크 기술, 도서출판 jinhan M\&B, 2005.

[9] 이근호, 민영훈, "U-City 기술전략과 RFID/USN의 U-City 응용”, 한국통신학회지, 제 22 권, 제7호, pp.26-40, 2005.

[10] 정경석, 문태헌, 허선영, "U-City 서비스 표준체계 정립과 서비스 분류기준의 설정에 관한 연구”, 국 토계획, 제44권, 제3호, pp.231-246, 2009.

[11] 정보통신연구진흥원, $u$-City 핵심 적용 기술 및 표준화 연구보고서, 경원대학교, 2005.

[12] 최봉문, “최근의 U-City 건설동향 분석과 도시계 획적 대응방안에 관한 연구”, 한국공간정보시스템 학회 2005년 추계학술대회 학술회의 논문집, pp.99-104, 2005.

[13] 최현미, 성아영, 최병주, 김재웅, "임베디드 소프 트웨어를 위한 기능중심 평가모델”, 한국정보과학 회 논문지, 제32권, 제12호, pp.1192-1205, 2005.

[14] B. Hofmann-Wellenhof and H. Lichtenegger, J. Collins, GPS 이론과 응용, 시그마프레스, 2001.

[15] 김정환, $M E M S$ 기술 및 시장동향, 주간기술동향 통권1322호, 정보통신산업진흥원, 2007.

[16] Ahmed Ashry, Khaled Sharaf, and Magdi Ibrahim, "A compact low-power UHIF RFID tag," Microelectronics Journal, In Press, 19 March. 2009.

[17] Bogdan Carbunar, Murali Krishna Ramanathan, Mehmet Koyuturk, Suresh Jagannathan, and Ananth Grama, "Efficient tag detection in RFID systems," Jounal of Parallel and Distributed Computing, Vol.69, No.2, pp.180-196, 2009.

[18] Christian Del Rosso, "Software performance tuning of software product family architectures : Two case studies in the real-time embedded systems domain," Journal of Systems and Software, Vol.81, No.1, pp.1-19, 2008.

[19] Dong-Her Shih, Po-Ling Sun, David C. Yen, and Shi-Ming Huang, "Taxonomy and survey of RFID anti-collision protocols," Computer Communications, Vol.29, No.11, pp.2150-2166, 2006.

[20] R. Eric Scerri and Jhon Worrall, "Prediction and the periodic table," Studies in History and 
Philosophy of Sciencert, Vol.32, No.3, pp.407-452, 2001.

[21] Fanny Coudert, "Towards a new generation of CCTV networks : Erosion of data protection safeguards?", Computer Law \& Security Review, Vol.25, No.2, pp.145-154, 2009.

[22] George Taylor, Chris Brunsdon, Jing Li, Andrew Olden, Dorte Steup, and Marylin Winter, "GPS accuracy estimation using map matching techniques: Applied to vehicle positioning and odometer calibration," Computers, Environment and Urban System, Vol.30, No.6, pp.757-772, 2006.

[23] Guangming Song, Yaoxin Zhou, Zhigang Wei, and Aiguo Song, "A smart node architecture for adding mobility to wireless sensor networks," Sensor and Actuators, Vol.142, No.1, pp.216-221, 2008.

[24] J. Aldridge and G. Knupfer, "Public safety : improving the effectiveness of CCTV security systems," Journal of the Forensic Science Society, Vol.34, No.4, pp.257-263, 1994.

[25] J. C. Kelly and Y. S Sherif, "Comparison of four design methods for real-time software development," Information and Software Technology, Vol.34, No.2, pp.74-82, 1992.

[26] John Ayoade, "Security implication in RFID and authentic processing framework," Computers \& Security, Vol.23, No.3, pp.207-212, 2006.

[27] D. Kensall and Wise, "Integrated sensors, MEMS, and microsystems : Reflection on a fantastic voyage," Sensors and Actuators, Vol.136, No.1, pp.39-50, 2007.

[28] M. Bigas, E. Cabruja, J. Forest, and J. Salvi, "Reniew of CMOS image sensors," Microelectronics Journal, Vol.37, No.5, pp.433-451, 2006.

[29] N. R. Poole, Q. Zhou, and P. Abatis, "Analysis of CCTV digital video recorder hard disk storage system," Digital Investigation, Vol.5, No.3-4, pp.85-92, 2009.

[30] Nobuyuki Ozaki, "Visually enhanced CCTV digital surveillance utilizing Intranet and Internet," ISA Transactions, Vol.41, No.3, pp.303-315, 2002.

[31] Pao-Ann Hsiung and Shang-Wei Lin, "Automatic synthesis and verification of real-time embedded software for mobile and ubiquitous systems," Computer Languages, System \& Structures, Vol.34, No.4, pp.153-169, 2008.

[32] Srdjan Krco, David Cleary, and daryl Parker, "Enabling ubiquitous sensor networking over mobile networks through peer-to-peer overlay networking," Computer Communications, Vol.28, No.13, pp.1586-1601, 2005.

[33] W. J. Yoon, S. H. Chung, and S. J. Lee, "Implementation and performance evaluation of an active RFID system for fast tag collection," Computer Communications, Vol.31, No.17, pp.4107-4116, 2008.

\section{저 자 소 개}

김 지 현(Ji-Hyun Kim) 정회원

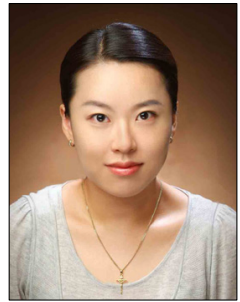

- 2004년 2월 : 충북대학교 지역건 설공학과(공학사)

- 2007년 2월 : 충북대학교 지역건 설공학과(공학석사)

- 2009년 3월 현재 : 서울대학교 건설환경공학부 박사과정

<관심분야> : U-Eco City 
김 호 기(Ho-Kee Kim)

정회원

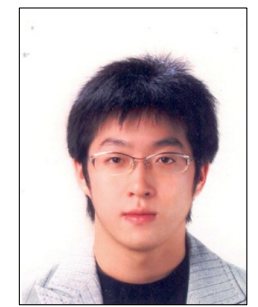

- 2006년 2월 : 서울대학교 지구환 경시스템공학부(공학사)

- 2008년 2월 : 서울대학교 건설환 경공학부(공학석사)

- 2008년 3월 현재 : 서울대학교 건설환경공학부 박사과정

<관심분야> : U-Eco City 